Marquette University

e-Publications@Marquette

Electrical and Computer Engineering Faculty

Research and Publications

Engineering, College of

5-1-2012

\title{
Analysis of the Detection of Organophosphate Pesticides in Aqueous Solutions Using Hydrogen- Bond Acidic Coating on SH-SAW Devices
}

Arnold Kweku Mensah-Brown

Marquette University

Darlington Mlambo

Marquette University

Fabien Josse PhD

Marquette University, fabien.josse@marquette.edu

Susan C. Schneider PhD

Marquette University, Susan.Schneider@marquette.edu

Accepted version. IEEE Sensors Journal, Vol. 12, No. 5 (May 2012): 893-903. DOI. (C) 2012 IEEE. Used with permission. 


\title{
Analysis of the Detection of Organophosphate Pesticides in Aqueous Solutions Using Hydrogen- Bond Acidic Coating on SH-SAW Devices
}

\author{
Arnold K. Mensah-Brown \\ Department of Electrical and Computer Engineering, \\ Marquette University \\ Milwaukee, WI \\ Darlington Mlambo \\ Department of Chemistry, Marquette University \\ Milwaukee, WI \\ Fabien Josse \\ Department of Electrical and Computer Engineering, \\ Marquette University \\ Milwaukee, WI \\ Susan C. Schneider \\ Department of Electrical and Computer Engineering, \\ Marquette University \\ Milwaukee, WI
}

IEEE Sensors Journal, Vol 12, No. 5 (May 2012): pg. 893-903. DOI. This article is @ Institute of Electrical and Electronics Engineers (IEEE) and permission has been granted for this version to appear in e-Publications@Marquette. Institute of Electrical and Electronics Engineers (IEEE)] does not grant permission for this article to be further copied/distributed or hosted elsewhere without the express permission from Institute of Electrical and Electronics Engineers (IEEE). 


\begin{abstract}
The work presented in this paper focuses on the synthesis and characterization of a hybrid organic/inorganic chemically sensitive layer for rapid detection and analysis of OPs in aqueous solutions using $\mathrm{SH}-\mathrm{SAW}$ devices. Coated SH-SAW devices on $36^{\circ} \mathrm{YX}-\mathrm{LiTaO}$ and $42.75^{\circ} \mathrm{YX}$-Quartz (ST$90^{\circ} \mathrm{X}$ Quartz), are used to determine the optimum operating conditions for achieving rapid sensor responses with high sensitivity. Three analytes (parathion-methyl, parathion, and paraoxon), having similar molecular mass and volume, are used to evaluate the performance of the hybrid organic/inorganic coating in terms of sensor properties of interest including sensitivity, selectivity, reproducibility. It is shown that the coating has a high degree of partial selectivity and sensitivity towards the analytes. With the present non-optimized chemical sensor, a limit of detection of 60 (ppb), 20 (ppb) and $100(\mathrm{ppb})$ is estimated for parathion-methyl, parathion, and paraoxon, respectively, when using a 0.5 -thick BPA-HMTS sensing layer. Concentrations as low as 500 (ppb) parathion have been measured. This concentration is significantly much lower than the typical concentrations found on agricultural produce ( $\geq 10 \mathrm{ppm}$ ).
\end{abstract}

\title{
Section I. Introduction
}

The presence of contaminants, including pesticides, in the environment continues to be of great concern to public health. Among the class of pesticides, the agro-industry has increasingly relied on organophosphate and carbamate pesticides because of their high insecticidal activity and relatively low persistence in the environment. ${ }^{1,2}$ However, recent research shows that organophosphate pesticides (OPs) persist in the environment for relatively long periods; ${ }^{2}$ as a result, their residues have been found in ground waters, soil, and agricultural products. These pesticides are toxic because they inhibit acetylcholinesterase, an enzyme that is required for the proper transmission of nerve impulses. Therefore, the presence of OPs in surface and ground water is a major concern to public health. In order to ensure the quality and safety of the water supply in various communities, early detection of contaminants is necessary.

Current methods for monitoring contaminants, such as OPs, include gas/liquid chromatography and mass spectroscopy. ${ }^{3}$ Although these methods are very accurate, they often require samples to be taken to laboratories for analysis, are extremely time consuming, and relatively expensive. Moreover, vital information can be lost during sample collection, transportation, and storage. Therefore, there is a need to develop in-situ monitoring systems for rapid analysis and characterization of samples. To make this possible, various

IEEE Sensors Journal, Vol 12, No. 5 (May 2012): pg. 893-903. DOI. This article is @ Institute of Electrical and Electronics Engineers (IEEE) and permission has been granted for this version to appear in e-Publications@Marquette. Institute of Electrical and Electronics Engineers (IEEE)] does not grant permission for this article to be further copied/distributed or hosted elsewhere without the express permission from Institute of Electrical and Electronics Engineers (IEEE). 
bio(chemical) sensor technologies including acoustic wave devices are being investigated to implement real-time sensing. ${ }^{3,4}$

The work presented in this paper focuses on the synthesis and characterization of a hybrid organic/inorganic chemically sensitive layer for rapid detection and analysis of OPs in aqueous solutions using $\mathrm{SH}-\mathrm{SAW}$ devices. SH-SAW devices on $36^{\circ} \mathrm{YX}-\mathrm{LiTaO}_{3}$ with center frequency of $103 \mathrm{MHz}$ and $42.75^{\circ} \mathrm{YX}$-Quartz (ST-90० X Quartz) with center frequency of $155 \mathrm{MHz}$ are used to determine the optimum operating conditions for achieving rapid sensor responses with high sensitivity. This work involves characterizing the coating (i.e., preparation techniques, water stability, aging, density, and glass transition temperature), characterizing the devices, and studying the effect of solution $\mathrm{pH}$ on analyte properties in aqueous solution. The analytes studied in this work are parathion-methyl, parathion, and paraoxon because of their extensive use and similarity in structure. The individual sensors are characterized by evaluating sensor properties of interest including reproducibility, sensitivity, selectivity, and other relevant sensor parameters. Understanding of the sensor response will allow one to design an optimum chemical sensor.

\section{Section II. Sensor Platform: Polymer-Coated SH- SAW Devices}

\section{A. Device Physics: Design and Principle of Operation}

The SH-SAW sensor can be modeled as a multilayered structure. ${ }^{5}$ The structure used in this investigation, shown in Fig. 1, is a three-layer structure which consists of the piezoelectric substrate, a polymer layer of finite thickness, $h$, and density, $\rho$, having a lower shear wave velocity than the substrate, and a liquid layer for transport of analyte molecules. The polymer layer acts as both the waveguide and the chemically sensitive layer. The guided SH-SAW is assumed to propagate in the $x_{1}$ direction, $x_{3}$ is normal to the sensing surface, and $x_{2}$ is in the direction of the acoustic wave particle displacement (or the aperture of the interdigital transducers (IDTs)).

IEEE Sensors Journal, Vol 12, No. 5 (May 2012): pg. 893-903. DOI. This article is (C) Institute of Electrical and Electronics Engineers (IEEE) and permission has been granted for this version to appear in e-Publications@Marquette. Institute of Electrical and Electronics Engineers (IEEE)] does not grant permission for this article to be further copied/distributed or hosted elsewhere without the express permission from Institute of Electrical and Electronics Engineers (IEEE). 


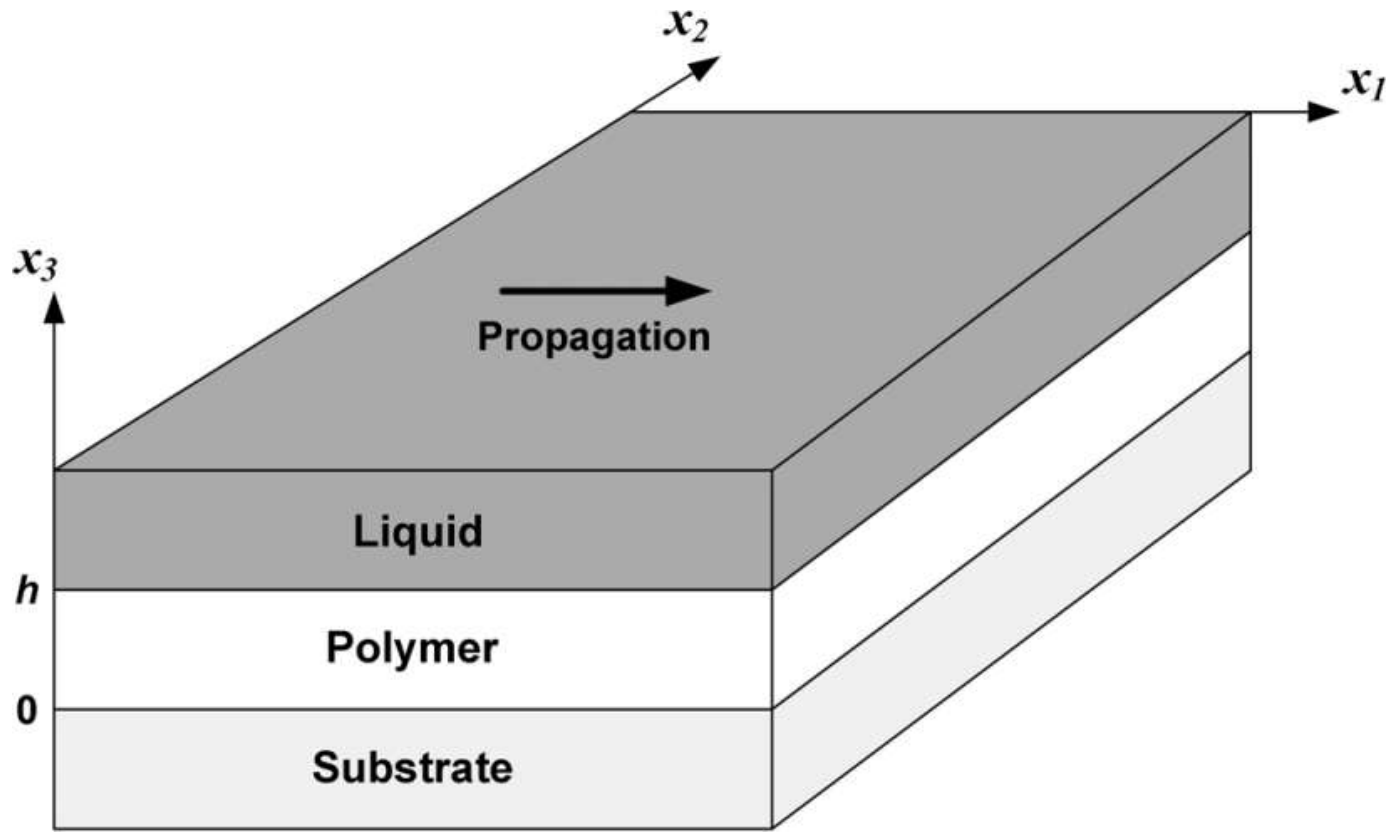

Fig. 1. Multilayer structure and coordinate system.

The liquid layer is assumed to be a Newtonian fluid because the solutions studied are dilute aqueous solutions. ${ }^{6}$ The effect of the polymer layer is to trap acoustic energy near the sensing surface, reducing propagation velocity and increasing the sensitivity to surface perturbation along the wave's propagation path. ${ }^{7}$ The amount of acoustic energy that is trapped by the polymer layer increases with film thickness up to an optimum value. Therefore, device sensitivity increases as the wave displacement amplitude increases at the surface i.e., as the film thickness is increased. ${ }^{8}$ Moreover, the polymer layer acts as the chemically sensitive layer i.e., sensing layer. The design of the SH-SAW device employs a dual delay line configuration with one line as a sensing line and the other as a reference. ${ }^{7}$ This design allows for common environmental interactions (such as temperature and pressure) eliciting responses from both lines to be eliminated by subtraction (known as differential measurement). Furthermore, a thin metal layer is used between the input and output IDTs to create an electrical short and eliminate acoustoelectric interaction within the propagation path. Therefore, only sensing caused by mechanical loading is considered in this work.

The polymer layer is characterized by a complex shear modulus, $G^{\prime}+j G^{\prime \prime}$, where $G^{\prime}$ and $G^{\prime \prime}$ are the shear storage modulus and loss 
modulus, respectively. The polymer is rigidly bonded to the surface of the piezoelectric substrate and undergoes both translation and deformation under the influence of the propagating wave. ${ }^{9}$ Translation causes a decrease in the SH-SAW velocity that is proportional to the areal mass density $(\rho h)$ of the film. This effect is known as mass loading $(m)$. In addition, the deformation produces energy storage in the film $\left(G^{\prime}\right)$, which results in a change in SH-SAW propagation velocity, and power dissipation in the film $\left(G^{\prime \prime}\right)$, which causes wave attenuation. ${ }^{9}$

When the polymer-coated SH-SAW device is exposed to analyte solution, the analyte absorbs into the coating resulting in additional mechanical loading. This mechanical loading is a combination of added mass $(\Delta m)$ and change in the complex shear modulus ( $\Delta G^{\prime}$ and $\Delta G^{\prime \prime}$ ) of the coating. ${ }^{10}$ For relatively low ambient concentrations, $\Delta m, \Delta G^{\prime}$ and $\Delta G^{\prime \prime}$ are proportional to the amount of analyte absorbed. ${ }^{11}$ Therefore, assuming that acoustoelectric interaction, temperature effects, and pressure effects have been eliminated, the observed frequency shift $(\Delta f)$ and change in insertion loss $\left(\Delta L_{I}\right)$ for a polymercoated SH-SAW device upon analyte absorption can be described by

$$
\begin{array}{cc}
\Delta f= & g_{1}\left(\Delta m, \Delta G^{\prime}\right) \\
\Delta L_{I}= & g_{2}\left(\Delta G^{\prime \prime}\right) .
\end{array}
$$

\section{B. Design of Sensor Coatings for Organophosphates}

A number of materials have been used as the chemically sensitive layer for the implementation of chemical microsensors. The materials range from conventional chromatographic stationary phases and polymers to unusual materials such as soot extracts. ${ }^{12}$ Regardless of the material, the key design challenge is the functionality of the coating and the extent to which it enhances the sensor performance in terms of sensitivity, selectivity, response time, reversibility, and reproducibility. Consequently, several factors have to be considered when selecting the coatings for sensing applications. For liquid-phase detection, the primary consideration is that the coating is stable in water ${ }^{13}$ and does not peel off or wash out under the experimental conditions in the liquid environment. Second, the glass transition temperature, $T_{g}$, of the polymer is considered. It is desirable that the

IEEE Sensors Journal, Vol 12, No. 5 (May 2012): pg. 893-903. DOI. This article is @ Institute of Electrical and Electronics Engineers (IEEE) and permission has been granted for this version to appear in e-Publications@Marquette. Institute of Electrical and Electronics Engineers (IEEE)] does not grant permission for this article to be further copied/distributed or hosted elsewhere without the express permission from Institute of Electrical and Electronics Engineers (IEEE) 
$T_{g}$ of the polymer coating be below room temperature and/or the operating temperature so that the sorption process is fast. ${ }^{12,14,15}$ For gas-phase sensing, it has been shown that vapor absorption and desorption is rapid when this condition is met, whereas the response times of sensors with glassy polymers are typically much slower than those of rubbery-based polymers. ${ }^{12}$ For experiments conducted with thin films on SAW devices, glassy polystyrene exhibited longer response times in contrast to the rapid responses for polysiloxanes films, which are low glass transition temperature materials. ${ }^{12}$ After considering the physical properties of the coating (which dictates aspects of the sensor performance such as stability, reproducibility, and response time), the chemical properties must also be considered because they influence the sensitivity and selectivity of the sensor. Therefore, the functional groups of the coating are considered so as to increase the strength of analyte/film interaction. These fundamental interactions include dispersion interactions, dipole-induced dipole interactions, dipole-dipole interactions, and hydrogen-bonding interaction (acidic analyte/basic coating or basic analyte/acidic coating). ${ }^{16}$ Vapor sorption (gas-phase sensing) as a function of these interactions has been systematically examined using linear solvation energy relationships (LSERs). ${ }^{12,17,18}$ Although LSERs has been performed for gas-phase sensing, the results can be used in aqueous environments as starting points to design polymer structures to promote particular interactions for improved sensitivity and selectivity. It is noted that, in liquid-phase sensing, the partition coefficient of the analyte-coating pair, a function of the LSERs, also depends on the analyte solubility. ${ }^{6}$

The analytes (OPs) studied in this work are organophosphorus compounds and exhibit strong hydrogen-bond basicity. Therefore, hydrogen-bond acidic polymers are ideal chemically sensitive layers for OP detection. A consideration of the chemical structures that lead to hydrogen-bond acidity leads to a choice of fluorinated alcohols and phenols as the functionality that should be incorporated into a polymer. ${ }^{18,19}$ Furthermore, studies done by Abraham et al. ${ }^{20}$ to compare hydrogen-bond acidities of several propyl- or allyl-substituted bisphenol structures using inverse gas chromatography and LSERs showed that fluorinated bisphenol-A structures were more hydrogenbond acidic than non-fluorinated analogues. ${ }^{18,20}$ These considerations 
provide the design criteria for the synthesis of the hybrid organic/inorganic sensing layer, bisphenol A-hexamethyltrisiloxane (dubbed BPA-HMTS), used in this work. The use of the HMTS monomer introduces the desired low $T_{g}$ and improves the adhesion of the thin film to the gold surface of the SH-SAW device while the Bisphenol A monomer provides targeted interactions for absorption of OPs. The coating was synthesized using the hydrosilylation reaction. ${ }^{14}$ It is worth noting, to our knowledge, that this coating has not been previously synthesized and characterized for the detection of organophosphate pesticides in aqueous solutions.

\section{Analyte Selection}

As mentioned earlier, OPs persist in the environment for relatively long periods. ${ }^{2}$ The persistence of OPs in surface and ground waters necessitates the development of in-situ real time monitoring systems for OPs. Parathion is one of the most commonly used OPs and is also one of the more persistent compounds in this class of pesticides. Furthermore, when it does degrade, its by-product ( $p$ nitrophenol) is still very toxic. ${ }^{21}$ It is for this reason that parathion is chosen as the primary analyte in this work, whereas the analogues, methyl parathion and paraoxon, are also selected to study the effect of the alkyl functional group and oxygen-analogue on the sensor response.

\section{Section III. Materials and Methods}

\section{A. Materials}

Chloroform (99.8\%), acetone (99\%), anhydrous toluene (99.8\%), 2-propanol, monobasic dihydrogen phosphate, 1,1,3,3,5 hexamethyltrisiloxane (HMTS), Platinum(0)-1,3-divinyl-1,1,3,3tetramethyldisiloxane (Pt-DVTMDS) complex solution in xylene (Pt 2\%), 2,2'-diallylbisphenol A (BPA), 2-ethoxyethylacetate (2EEA), dibasic monohydrogen phosphate, parathion-methyl, parathion, and paraoxon were purchased from Sigma-Aldrich (Milwaukee, WI) and used as supplied. Poly (methyl methacrylate) (PMMA), Mw 35,000, was purchased from Scientific Polymer Products and used as supplied. 


\section{B. Coating Synthesis and Characterization}

BPA-HMTS was synthesized by modifying a procedure reported by Grate et al. ${ }^{22}$ Briefly, $(0.882 \mathrm{~g}, 0.00286 \mathrm{~mol})$ of BPA $\left(M_{\mathrm{w}}=308.41 \mathrm{~g} / \mathrm{mol}\right)$ was dissolved in $10 \mathrm{~mL}$ of toluene in a vial. This mixture was stirred for about $5 \mathrm{~min}$. until a homogeneous mixture was obtained. To this solution, $(0.566 \mathrm{~g}, 0.00271 \mathrm{~mol})$ of HMTS $\left(M_{w}=208.48 \mathrm{~g} / \mathrm{mol}\right)$ was added to give a mole ratio for reacting functional groups, $r=[\mathrm{SiH}] /[\mathrm{CH} 2=\mathrm{CH}]$, of $0.95 .10 \mathrm{~mL}$ of toluene was added to this solution, stirred for about $1 \mathrm{~min}$, and the presence of the $\mathrm{Si}-\mathrm{H}\left(2125 \mathrm{~cm}^{-1}\right)$ group monitored by FTIR. Two drops $(\sim 0.02 \mathrm{~g})$ of PtDVTMDS was added and the solution was heated and stirred at 110$115^{\circ} \mathrm{C}$ in an oil bath. After 20 minutes, all of the Si-H had been consumed. This was confirmed by the disappearance of the $\mathrm{Si}-\mathrm{H}$ group in the FTIR spectra (see Fig. 1). $0.17 \mathrm{~g}$ (for a total of $0.736 \mathrm{~g}, 0.00353$ mol, $r=1.23$ ) of HMTS was added to the reaction mixture so that excess $\mathrm{Si}-\mathrm{H}$ was detected in the FTIR spectra. Five drops $(\sim 0.058 \mathrm{~g})$ of the catalyst were added in order to terminate the polymer with vinyl groups. Polymerization took place in a three-neck round-bottom flask using a reflux set-up in an oil bath at $100-110^{\circ} \mathrm{C}$ for 2 hours while stirring. At the end of the reaction, the catalyst was removed by adding activated carbon followed with filtering of the solution. Toluene was then removed by rotary evaporation. Subsequently, the sample was transferred to a watch glass and heated under vacuum at $60^{\circ} \mathrm{C}$ for 36 hours to remove residual solvent.

Spectroscopic characterization was obtained on a Perkin Elmer Spectrum 100 FTIR spectrometer and Varian 400 NMR spectrometer. Differential Scanning Calorimetry (DSC) was perfomed under nitrogen on a DSC 822e Mettler Toledo Inc (Columbus Ohio) instrument. Glass transition temperature, $T_{g}$, is reported as the inflection point in the DSC trace. Decomposition temperature, $T_{d}$, is reported as the temperature at $10 \%$ mass loss in Thermogravimetric data. The film density, $\rho_{f}$, was estimated using a $1 \mathrm{~mL}$ volumetric flask. Briefly, $4.4 \%$ wt BPA-HMTS in chloroform was prepared. The empty flask with the stopper was then weighed $\left(W_{1}\right)$ and partially filled (50\%) with BPA-HMTS solution. The flask was placed in an oven and heated at $50^{\circ} \mathrm{C}$ for $24 \mathrm{hrs}$ to remove the solvent. Afterwards, the flask with the lid and just the polymer was weighed $\left(W_{2}\right)$. The flask was then filled

IEEE Sensors Journal, Vol 12, No. 5 (May 2012): pg. 893-903. DOI. This article is @ Institute of Electrical and Electronics Engineers (IEEE) and permission has been granted for this version to appear in e-Publications@Marquette. Institute of Electrical and Electronics Engineers (IEEE)] does not grant permission for this article to be further copied/distributed or hosted elsewhere without the express permission from Institute of Electrical and Electronics Engineers (IEEE). 
with deionized (DI) water to a total volume of $1 \mathrm{~mL}$ and weighed $\left(W_{3}\right)$. The density of the film $\left(\rho_{f}\right)$, in $\mathrm{g} / \mathrm{cm}^{3}$, was then estimated using the relation

$$
\rho_{f}=\frac{\text { Mass }}{\text { Volume }}=\frac{W_{2}-W_{1}}{1-V_{1}}
$$

where the volume of water, $V_{1}$, is given by $W_{3}-W_{2}$ because the density of water is $1 \mathrm{~g} / \mathrm{cm}^{3}$. The results obtained for the FTIR characterization are shown in Fig. 2, where the presence of the $\mathrm{OH}$ functional group for analyte interaction and the appearance and disappearance $(\mathrm{Si}-\mathrm{H})$ is circled. The $T_{g}$ and, $\rho_{f}$ are found to be $4.95^{\circ} \mathrm{C}$ and $1.15 \mathrm{~g} / \mathrm{cm}^{3}$, respectively.

\section{Analyte Characterization}

As indicated earlier, the three analytes (parathion-methyl, parathion, and paraoxon) were chosen to study the effect of the alkyl functional group and oxygen-analogue on the sensor response. The physical properties for these analytes are shown in Table I. Note that the analytes have nearly identical molar masses and volumes and the slight difference in physical properties is due to the alkyl group, sulfur atom, and oxygen atom in their chemical structures.

Table I. Physical Properties of Analytes

\begin{tabular}{|c|c|c|c|c|}
\hline Analyte & $\begin{array}{c}\text { Molar Mass } \\
(\mathbf{g} / \mathbf{m o l})\end{array}$ & $\begin{array}{c}\text { Area } \\
\left(\mathbf{A}^{2}\right)\end{array}$ & $\begin{array}{c}\text { Volume } \\
\left(\mathbf{A}^{3}\right)\end{array}$ & $\begin{array}{c}\text { Solubility } \\
(\mathbf{p p m} \text { or } \mathbf{~ m g} / \mathbf{L})\end{array}$ \\
\hline Parathion-Methyl & 263.21 & $267.18^{\mathrm{a}}$ & $227.73^{\mathrm{a}}$ & $38.0^{\mathrm{b}}$ at $20^{\circ} \mathrm{C}$ \\
\hline Parathion & 291.26 & $298.26^{\mathrm{a}}$ & $261.30^{\mathrm{a}}$ & $12.9^{\mathrm{b}}$ at $20^{\circ} \mathrm{C}$ \\
\hline Paraoxon & 275.20 & $290.05^{\mathrm{a}}$ & $251.72^{\mathrm{a}}$ & Not available \\
\hline
\end{tabular}

IEEE Sensors Journal, Vol 12, No. 5 (May 2012): pg. 893-903. DOI. This article is @ Institute of Electrical and Electronics Engineers (IEEE) and permission has been granted for this version to appear in e-Publications@Marquette. Institute of Electrical and Electronics Engineers (IEEE)] does not grant permission for this article to be further copied/distributed or hosted elsewhere without the express permission from Institute of Electrical and Electronics Engineers (IEEE). 
NOT THE PUBLISHED VERSION; this is the author's final, peer-reviewed manuscript. The published version may be accessed by following the link in the citation at the bottom of the page.

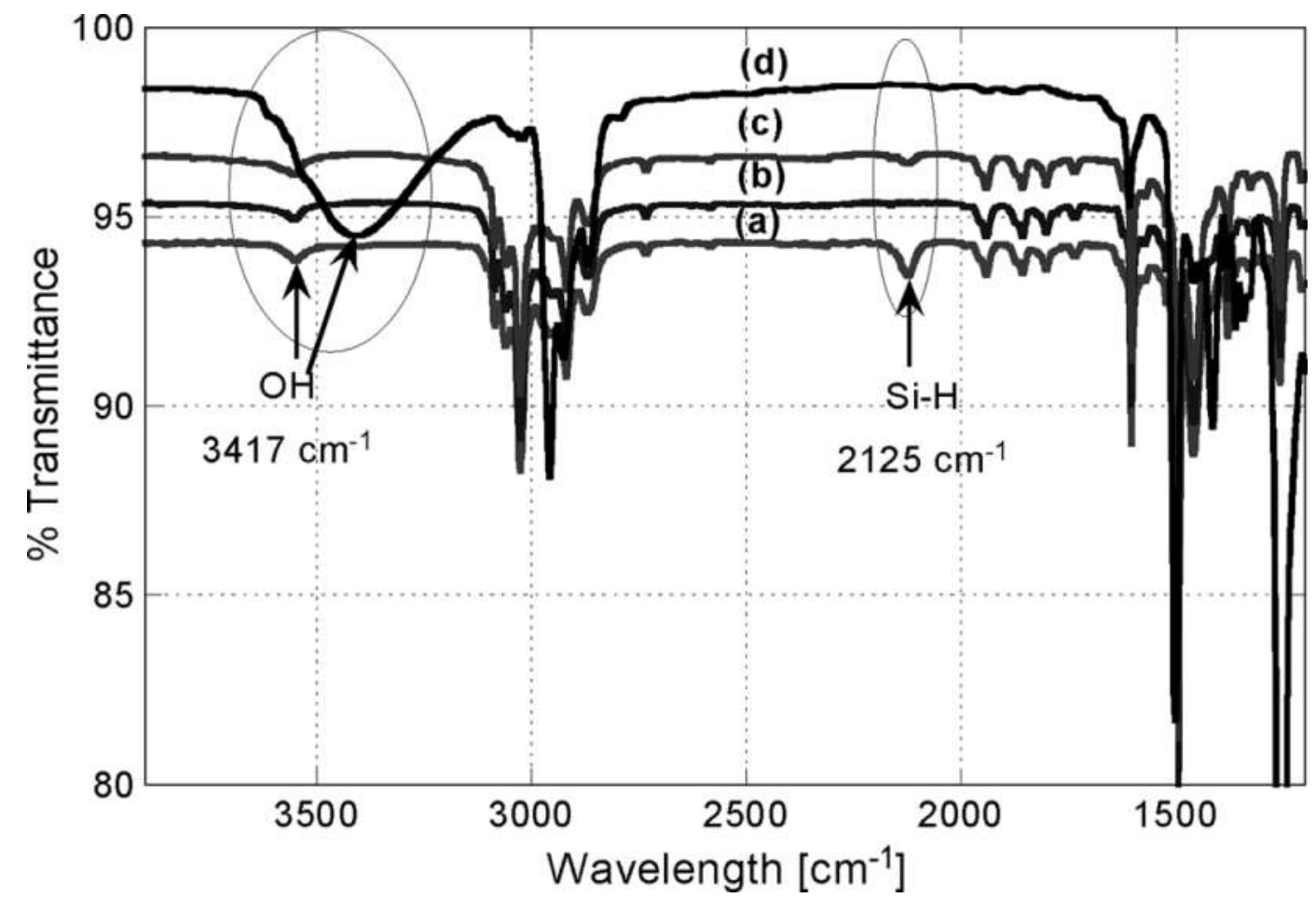

Fig. 2. FTIR spectra characterization for the funtionalization of $1,1,3,3,5,5-$ hexamethyltrisiloxane (HMTS) with 2,2'-diallybisphenol A (BPA) using the hydrosilylation reaction (a) before adding catalyst (b) after adding catalyst and stirring for 20 min (c) after adding excess HMTS and stirring for 20 min (d) final product after evaporation of the solvent.

IEEE Sensors Journal, Vol 12, No. 5 (May 2012): pg. 893-903. DOI. This article is @ Institute of Electrical and Electronics Engineers (IEEE) and permission has been granted for this version to appear in e-Publications@Marquette. Institute of Electrical and Electronics Engineers (IEEE)] does not grant permission for this article to be further copied/distributed or hosted elsewhere without the express permission from Institute of Electrical and Electronics Engineers (IEEE). 
NOT THE PUBLISHED VERSION; this is the author's final, peer-reviewed manuscript. The published version may be accessed by following the link in the citation at the bottom of the page.
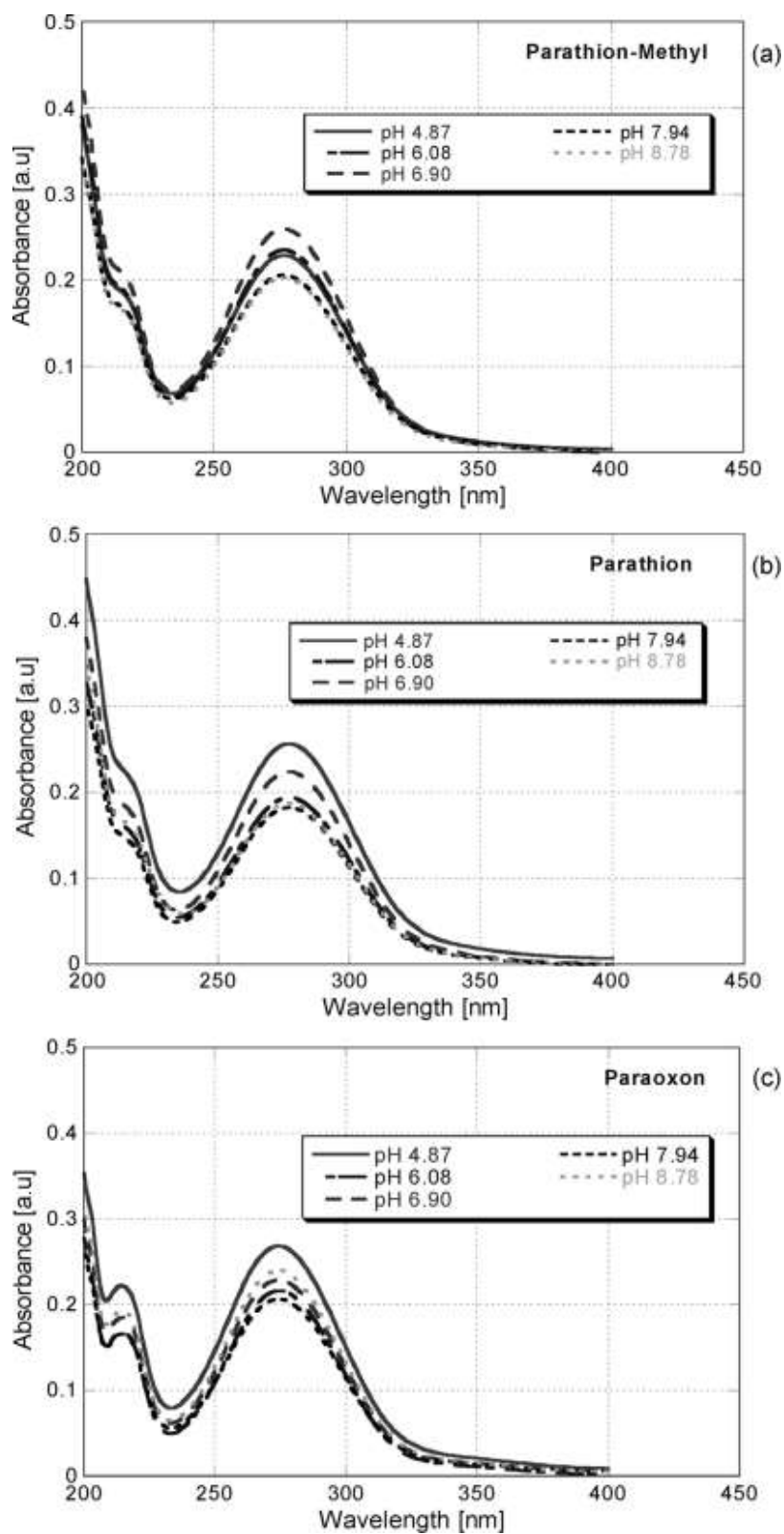

Fig. 3. UV-vis absorption spectra for (a) parathion-methyl, (b) parathion, and (c) paraoxon in the $\mathrm{pH}$ range typically found in groundwater (i.e., 4.9-8.8). The absorption spectra in both (a), (b), and (c) do not change in the studied $\mathrm{pH}$ range, indicating that the analyte characteristics are not affected by $\mathrm{pH}$ in this range.

In aqueous solutions, OPs degrade by means of chemical hydrolysis..$^{2,23,24}$ In general, this reaction is a first order process. ${ }^{2,24}$ They also exhibit a second-order breakdown process in which the hydrolysis reaction depends on the $\mathrm{pH}$ of the solution. ${ }^{2}$ Therefore, for chemical sensing applications, it is critical to determine whether the same compound exists at different pHs. To study the effect of solution

IEEE Sensors Journal, Vol 12, No. 5 (May 2012): pg. 893-903. DOI. This article is C Institute of Electrical and Electronics Engineers (IEEE) and permission has been granted for this version to appear in e-Publications@Marquette. Institute of Electrical and Electronics Engineers (IEEE)] does not grant permission for this article to be further copied/distributed or hosted elsewhere without the express permission from Institute of Electrical and Electronics Engineers (IEEE). 
$\mathrm{pH}$ on the temporal behaviour of the reacting species (deprotonated and protonated) for the decomposition of the analytes in aqueous solutions, the concentration of analyte in solution was fixed at $6 \mathrm{ppm}$ ( $\mathrm{mg} / \mathrm{L})$. The UV absorbance of the analytes at various $\mathrm{pH}$ conditions was then measured. It is noted that protonated and deprotonated species possess different absorbance characteristics of UV light at various wavelengths. ${ }^{25}$ From Fig. 3 , it is seen that the absorption spectra in both (a), (b), and (c) do not change in the studied $\mathrm{pH}$ range, indicating that the analyte characteristics are not affected by $\mathrm{pH}$ in this range i.e., the species distribution does not change. The variation in absorbance may be due to slight variation in analyte concentration. Similar results were found for diazinon, another OP, in. ${ }^{25}$ Here, the hydrolytic rate constant was found to be approximately zero for the $\mathrm{pH}$ range $4-10$. Based on these results, a phosphate buffer solution of $\mathrm{pH} 6.20 \pm 0.3$ is used as a reference in this work because it offers a suitable compromise in the range from $\mathrm{pH} 5.5$ to 8.5 typically found in surface, ground, and river waters. ${ }^{2,24,26}$

\section{Devices}

$\mathrm{SH}-\mathrm{SAW}$ devices on $\mathrm{LiTaO}_{3}$ coated with the polymer layer are used as the primary sensor platform for the implementation of highsensitivity chemical detectors for OPs in liquid environments. This substrate has both a high piezoelectric coupling constant and a high dielectric constant of $\varepsilon=47$. The high piezoelectric coupling coefficient allows for the implementation of low-loss acoustic wave devices, and the high dielectric constant helps confine a sufficient portion of the electric fields generated by the IDTs to the substrate, even in direct contact with aqueous solutions $(\varepsilon=75) .{ }^{7}$ Therefore, both the transducer and propagation path are exposed to the solution of interest, as shown in Fig. 4(a). 


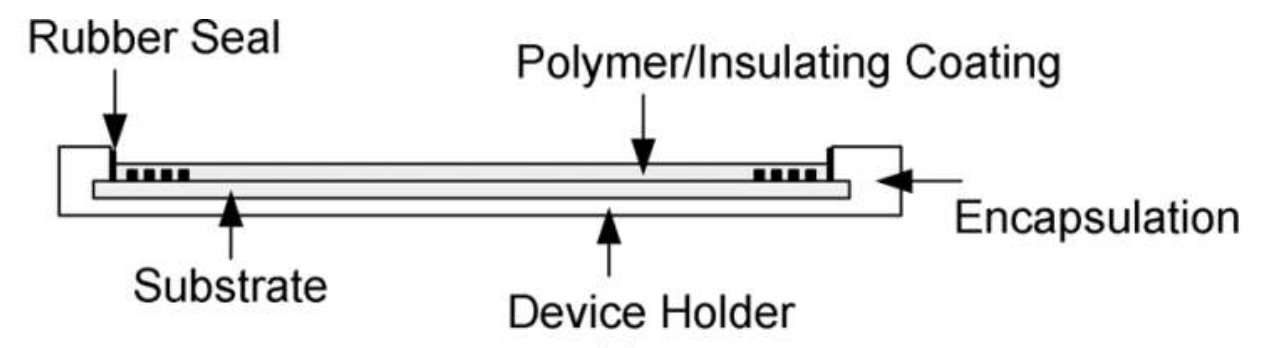

(a)

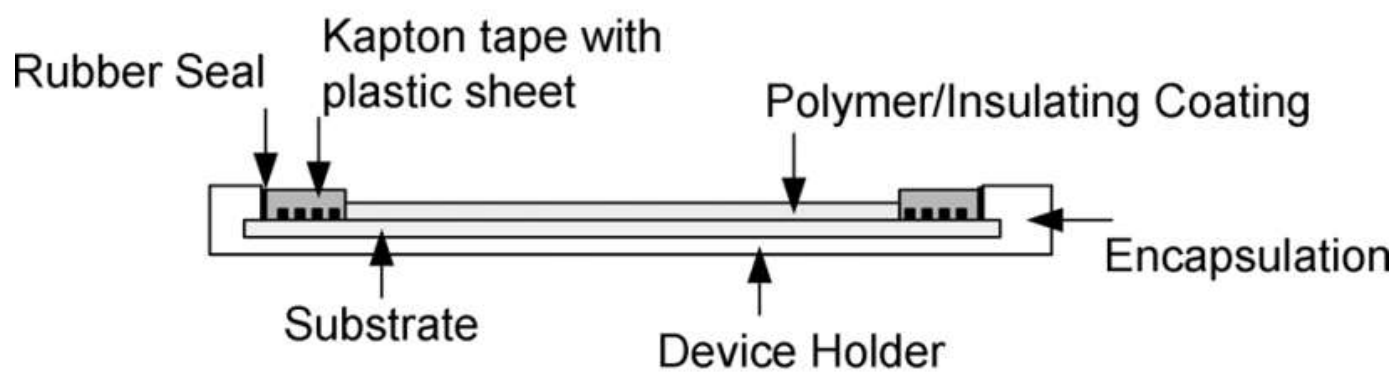

(b)

Fig. 4. Transducer passivation (a) $\mathrm{LiTaO}_{3}$ (b) Quartz.

The device is fabricated on a $36^{\circ}$ rotated Y-cut X-propagation Lithium tantalate $\left(36^{\circ} \mathrm{YX}-\mathrm{LiTaO}_{3}\right)$ piezoelectric substrate. ${ }^{11,27}$ The device utilized $10 / 80 \mathrm{~nm}$ thick $\mathrm{Cr} / \mathrm{Au}$ split finger IDTs having a periodicity of $40 \mu \mathrm{m}$, which corresponds to an operating frequency of approximately $103 \mathrm{MHz}$ for the uncoated devices. ${ }^{28} \mathrm{SH}-\mathrm{SAW}$ devices on quartz are also investigated for sensitivity comparison in liquid environments. However, this substrate has a relatively low piezoelectric coupling coefficient as well as a low dielectric constant of $\varepsilon=4.5$. As a result, when the substrate is in direct contact with aqueous solutions, the electric fields generated by the IDTs is not confined to the substrate and consequently the generated acoustic wave is significantly attenuated. To overcome this problem, fused quartz layers (6 to $10 \mu \mathrm{m}$ ) are typically used to shield the IDTs. In this work, a novel solution combining Kapton tape and a plastic sheet of thickness $25 \mu \mathrm{m}$ and $12.7 \mu \mathrm{m}$, respectively, is used to shield the IDTs. The plastic sheet is used to reduce the amount of attenuation caused by the silicone adhesive on the tape. As a result, only the propagation path was coated on the quartz device for sensing purpose, as shown in Fig. 4(b).

The quartz device was fabricated on ST- $90^{\circ}$ quartz crystal. The devices are fabricated with 120-nm-thick $\mathrm{Cr} / \mathrm{Au}(20 / 100 \mathrm{~nm})$ split 
finger IDTs having a period of $32 \mu \mathrm{m}$. This corresponds to an operating frequency of approximately $155 \mathrm{MHz}$ for the uncoated devices. ${ }^{28} \mathrm{~A}$ dual delay line configuration is used in both devices, in which one line acts as the reference line and the other as the sensing line. A top view for the layout of the sensors can be found in. ${ }^{28}$

\section{E. Measurement Procedures}

The measurement set-up consists of the coated guided SH-SAW device, a flow cell for exposing the coated device to the solution of interest, a peristaltic pump, a vector network analyzer (VNA), and a PC-Based HP VEE program for collecting data (loss, phase, frequency, and temperature). In this study, temperature control of the sensor was achieved by using differential measurement. Since the frequencytemperature characteristics of PMMA is different from that of BPAHMTS, additional temperature control was implemented. Here, the device holder was placed in contact with a Peltier thermo-electric cooler (TEC) module. The TEC was mounted on a heat sink and placed in a temperature controlled chamber. A MAX1978 PC board, a DC power supply, and a $10 \mathrm{k} \Omega$ NTC thermistor (YSI 44006) was used to implement a temperature control system for the Peltier TEC module.

Before depositing the film, the devices were first cleaned for 3 min in ultrasonic baths of chloroform, acetone, and 2-propanol, respectively. The devices are then rinsed with Milli-Q de-ionized (DI) water and dried with nitrogen. Afterwards, $14.95 \%$ wt PMMA solution in $2 \mathrm{EEA}$ is spin coated onto the reference line for a $0.5 \mu \mathrm{m}$-thick layer. The film was then baked at $180^{\circ} \mathrm{C}$ for 90 minutes to remove trace of solvent and to further reduce analyte absorption. After cooling, BPAHMTS solutions of either $2.8,4.6,5.6,6.6$, and $7.0 \%$ wt prepared in chloroform was spin coated to obtain $0.25,0.5,0.73,1.06$, and 1.23 $\mu \mathrm{m}$-thick layers, respectively, on the sensing line. The coated device was allowed to dry at room temperature $21.7-22.5^{\circ} \mathrm{C}$ in a desiccator for at least 15 hours. The film thickness was calibrated using identical coating conditions to deposit films on glass slides having the same dimensions as the devices and performing step-height measurement.

A reference solution was created by mixing $960 \mathrm{~mL}$ of phosphate buffer solution (PBS) $[\mathrm{pH}=6.20 \pm 0.05]$ with $1.11 \mathrm{~mL}$ of methanol and stirring for 1 hour at $1000 \mathrm{rpm}$. Afterwards, a

IEEE Sensors Journal, Vol 12, No. 5 (May 2012): pg. 893-903. DOI. This article is @ Institute of Electrical and Electronics Engineers (IEEE) and permission has been granted for this version to appear in e-Publications@Marquette. Institute of Electrical and Electronics Engineers (IEEE)] does not grant permission for this article to be further copied/distributed or hosted elsewhere without the express permission from Institute of Electrical and Electronics Engineers (IEEE). 
concentrated solution of parathion-methyl, parathion, and paraoxon were prepared by mixing $24.1 \mu \mathrm{L}, 25.8 \mu \mathrm{L}$, and $25.7 \mu \mathrm{L}$ in $3 \mathrm{~mL}$ of methanol, respectively. Here, methanol is used to increase the solubility of the analytes in water. From each stock solution, $140 \mu \mathrm{L}$ aliquots were added to $120 \mathrm{~mL}$ of phosphate buffer solution PBS to create a solution of approximately $12.64 \mathrm{mg} / \mathrm{L}(\mathrm{ppm})$ parathion-methyl, $12.62 \mathrm{mg} / \mathrm{L}$ (ppm) parathion, and $12.61 \mathrm{mg} / \mathrm{L}(\mathrm{ppm})$ paraoxon, respectively. Each solution is then diluted with the reference solution to obtain desired concentrations. Diluting with the reference solution ensures that the $\mathrm{pH}$ of the solutions is constant from sample to sample.

A typical experimental run is started by exposing the coated device to the reference solution at a flow rate of $0.70 \mathrm{~mL} / \mathrm{min}$ until the frequency response is stable. The coated device is then exposed to various analyte concentrations. Between analyte exposures, the sensor response was returned to its initial value by flushing the flow-cell with the reference solution. The differential measurement thus reflects the sensor response due to perturbations caused by only analyte absorption.

\section{Section IV.Results and Discussion}

\section{A. Device Characterization}

The sensitivity of chemical sensors depends on both the transducer (sensor device) and chemically sensitive layer used. For this reason, the performances of two different acoustic wave-based chemical sensors are compared as a function of operating frequency and piezoelectric substrate. The two devices used here are a lithium tantalate $\left(\mathrm{LiTaO}_{3}\right)$ device operating at $103 \mathrm{MHz}$ (LT103) and a quartz device operating at $155 \mathrm{MHz}$ (Q155).

Two configurations were used for the deposition of BPA-HMTS because the piezoelectric substrates have different permittivity. For the LT103, both the propagation path and IDTs were coated with BPAHMTS. This was done to minimize device loss and signal distortion. For the Q155, only the propagation path was coated. 
Before each experiment, the transmission spectra of the uncoated device, the coated device in air, and the coated device in the reference solution were measured. The deposition of a lossy polymer layer trapped the acoustic energy to the surface and minimized the ripples present in the passband as a result of the loss through tripletransit interference (TTI). ${ }^{29}$ The result is an improved phase linearity in the passband, hence lower distortion of the sensor signal and improved reproducibility. Also, immersion in liquid results in a downward shift of the phase as a result of mass loading and change in the viscoelastic properties of the coating due to water and other molecules present in the reference solution. The major difference between Q155 and LT103 is that the uncoated Q155 device has a lower passband distortion and better phase linearity. This is because the excitation of unwanted bulk waves is minimal and outside the device's passband for this quartz orientation. The characteristics of the two coated devices in air and reference solution are similar with the exception that the quartz sensor system has a higher loss because only the propagation path is coated and the adhesive of the Kapton tape acts as an acoustic absorber; the average loss at the operating frequency of $101.4 \mathrm{MHz}$ and $155.4 \mathrm{MHz}$ is $-30 \mathrm{~dB}$ and $-35 \mathrm{~dB}$ for LT103 and Q155, respectively. It is noted that the thickness of the BPA-HMTS layer on Q155 was limited to less than $0.5 \mu \mathrm{m}$ because this thickness resulted in higher loss $(-40 \mathrm{~dB})$.

\section{B. Sensor Response and Discussion}

IEEE Sensors Journal, Vol 12, No. 5 (May 2012): pg. 893-903. DOI. This article is @ Institute of Electrical and Electronics Engineers (IEEE) and permission has been granted for this version to appear in e-Publications@Marquette. Institute of Electrical and Electronics Engineers (IEEE)] does not grant permission for this article to be further copied/distributed or hosted elsewhere without the express permission from Institute of Electrical and Electronics Engineers (IEEE). 
NOT THE PUBLISHED VERSION; this is the author's final, peer-reviewed manuscript. The published version may be accessed by following the link in the citation at the bottom of the page.
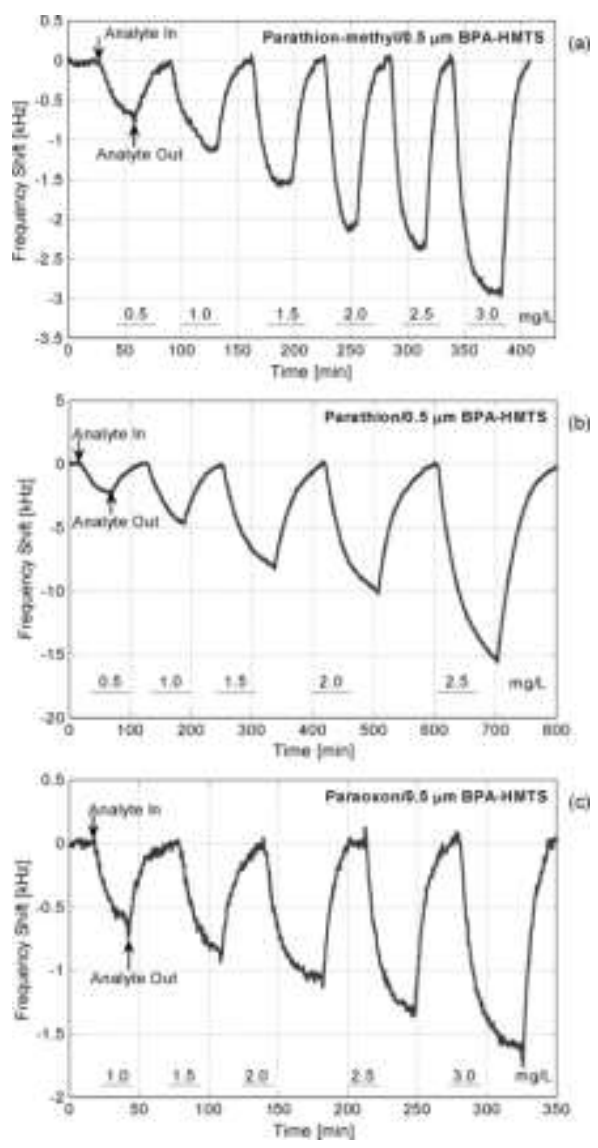

Fig. 5. Measured frequency shifts in the detection of (a) $500 \mu \mathrm{g} / \mathrm{L}$ (ppb) to $3.0 \mathrm{mg} / \mathrm{L}$ (ppm) of parathion-methyl; (b) $500 \mu \mathrm{g} / \mathrm{L}$ (ppb) to $2.5 \mathrm{mg} / \mathrm{L}$ (ppm) of parathion; (c) 1 $\mathrm{mg} / \mathrm{L}(\mathrm{ppm})$ to $3.0 \mathrm{mg} / \mathrm{L}$ (ppm) of paraoxon using $0.5 \mu \mathrm{m}$-thick BPA-HMTS on $\mathrm{LiTaO}_{3}$ SH-SAW device.

IEEE Sensors Journal, Vol 12, No. 5 (May 2012): pg. 893-903. DOI. This article is @ Institute of Electrical and Electronics Engineers (IEEE) and permission has been granted for this version to appear in e-Publications@Marquette. Institute of Electrical and Electronics Engineers (IEEE)] does not grant permission for this article to be further copied/distributed or hosted elsewhere without the express permission from Institute of Electrical and Electronics Engineers (IEEE). 
NOT THE PUBLISHED VERSION; this is the author's final, peer-reviewed manuscript. The published version may be accessed by following the link in the citation at the bottom of the page.
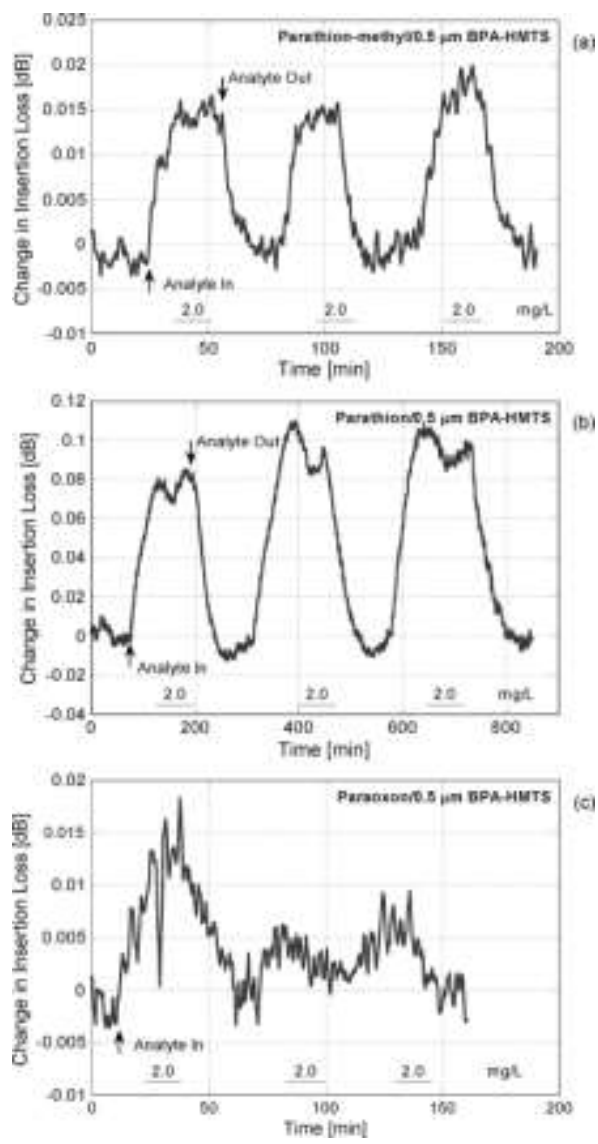

Fig. 6. Measured change in insertion loss in the repeated detection of $2 \mathrm{mg} / \mathrm{L}$ of (a) parathion-methyl, (b) parathion, and (c) paraoxon using a $0.5 \mu$ m-thick BPA-HMTS layer on $\mathrm{LiTaO}_{3} \mathrm{SH}-\mathrm{SAW}$ device.

IEEE Sensors Journal, Vol 12, No. 5 (May 2012): pg. 893-903. DOI. This article is @ Institute of Electrical and Electronics Engineers (IEEE) and permission has been granted for this version to appear in e-Publications@Marquette. Institute of Electrical and Electronics Engineers (IEEE)] does not grant permission for this article to be further copied/distributed or hosted elsewhere without the express permission from Institute of Electrical and Electronics Engineers (IEEE). 
NOT THE PUBLISHED VERSION; this is the author's final, peer-reviewed manuscript. The published version may be accessed by following the link in the citation at the bottom of the page.

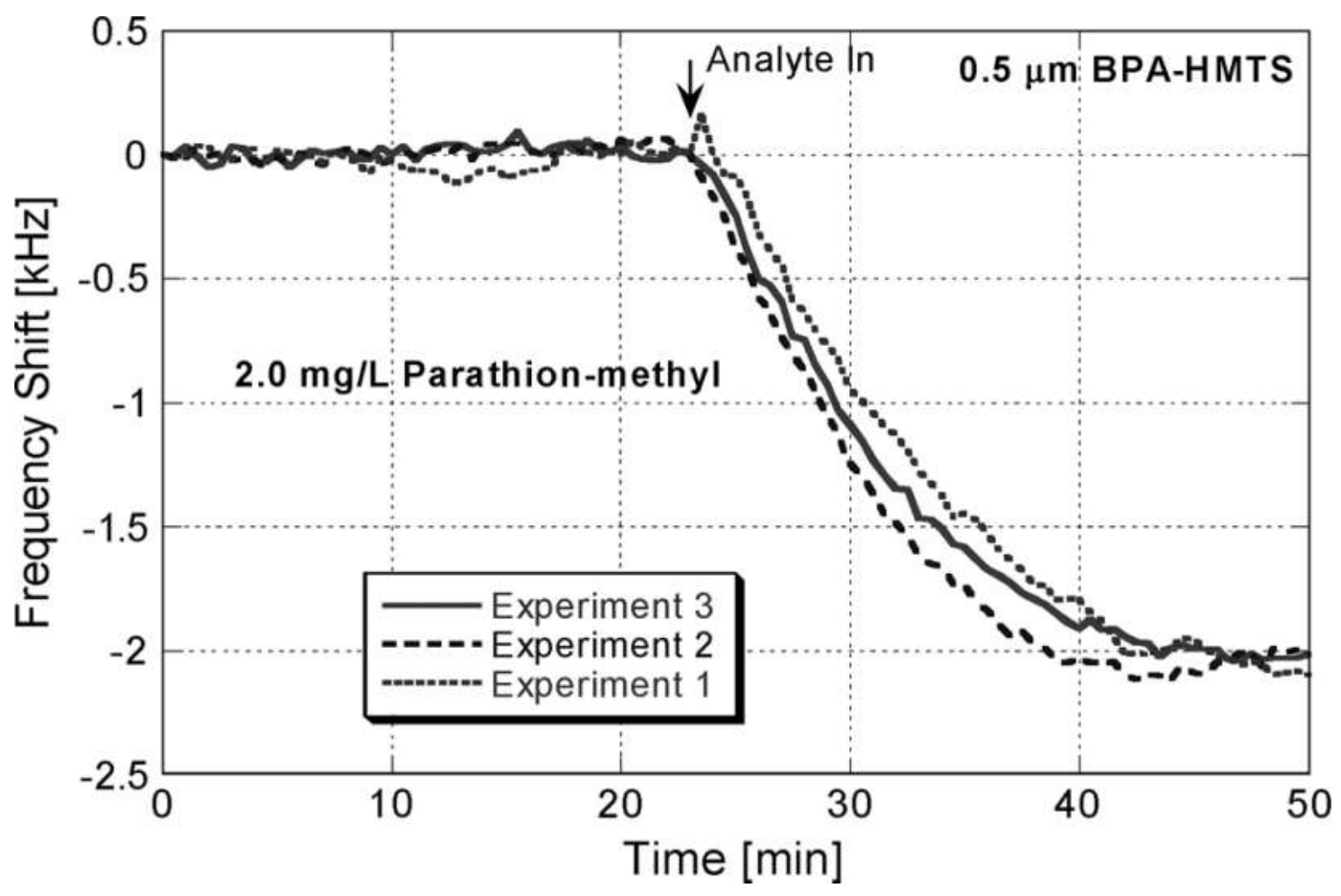

Fig. 7. Measured frequency response for three independent experiments in the detection of $2.0 \mathrm{mg} / \mathrm{L}$ of parathion using a $0.5 \mu$ m-thick BPA-HMTS layer on $\mathrm{LiTaO}_{3}$ SH-SAW device.

Several experiments were conducted for three analyte/coating pairs for the same coating thickness. Fig. 5 shows sensor responses (frequency shift) for a guided SH-SAW sensor coated with $0.5 \mu \mathrm{m}$ thick BPA-HMTS exposed to various concentrations of parathionmethyl $(0.5-2.5 \mathrm{mg} / \mathrm{L}(\mathrm{ppm}))$, parathion $(0.5-2.5 \mathrm{mg} / \mathrm{L}(\mathrm{ppm}))$ and paraoxon (1-3 $\mathrm{mg} / \mathrm{L}(\mathrm{ppm})$ ) in aqueous solutions. The reversible nature of the sensor response indicates that the analyte/coating interaction is physical rather than chemical. Therefore, the present sensor could be reused. Within the measured range, the frequency shift $(\Delta f)$ is linear with analyte concentration and any slight deviations from linearity may be due to fluctuations in the concentration of the prepared solutions. Fig. 6 shows the change in loss for repeated exposure to $2 \mathrm{mg} / \mathrm{L}$ of parathion-methyl, parathion, and paraoxon, respectively. It is seen that the device loss increases as a result of the coating becoming more rubbery upon analyte absorption, with parathion producing the greatest change in loss, an indication of larger plasticization effect. In Fig. 7, the same device was used in three different experiments to demonstrate reproducibility/stability of the measurement. Note that the signal variation for the baseline is

IEEE Sensors Journal, Vol 12, No. 5 (May 2012): pg. 893-903. DOI. This article is @ Institute of Electrical and Electronics Engineers (IEEE) and permission has been granted for this version to appear in e-Publications@Marquette. Institute of Electrical and Electronics Engineers (IEEE)] does not grant permission for this article to be further copied/distributed or hosted elsewhere without the express permission from Institute of Electrical and Electronics Engineers (IEEE). 
relatively small and the value for the steady-state frequency shift are in good agreement.

As discussed earlier, change in the guided $\mathrm{SH}-\mathrm{SAW}$ response is due to changes in the film properties as a result of analyte sorption. Because the film is rigidly bonded to the substrate, it experiences translation and deformation under the influence of the traveling wave. ${ }^{9}$ Translation motion produces a decrease in the SAW velocity that is proportional to the areal mass density contributed by the film-mass loading; film deformation produces energy storage (change in storage modulus, $G^{\prime}$ ) and power dissipation in the film (change in the loss modulus, $\left.G^{\prime \prime}\right)$, which change the phase velocity and attenuation, respectively. ${ }^{9}$ In Fig. 6 , it is seen that the device loss increases as a result of the coating becoming more rubbery upon analyte absorption, i.e., $G^{\prime \prime}$ increases upon analyte absorption. This is in agreement with the positive change typically measured for the loss due to changes in the viscoelastic properties of the film upon analyte absorption ${ }^{6}$ with the loss modulus effect on the attenuation being attributed to film plasticization or analyte induced softening and swelling.9,30

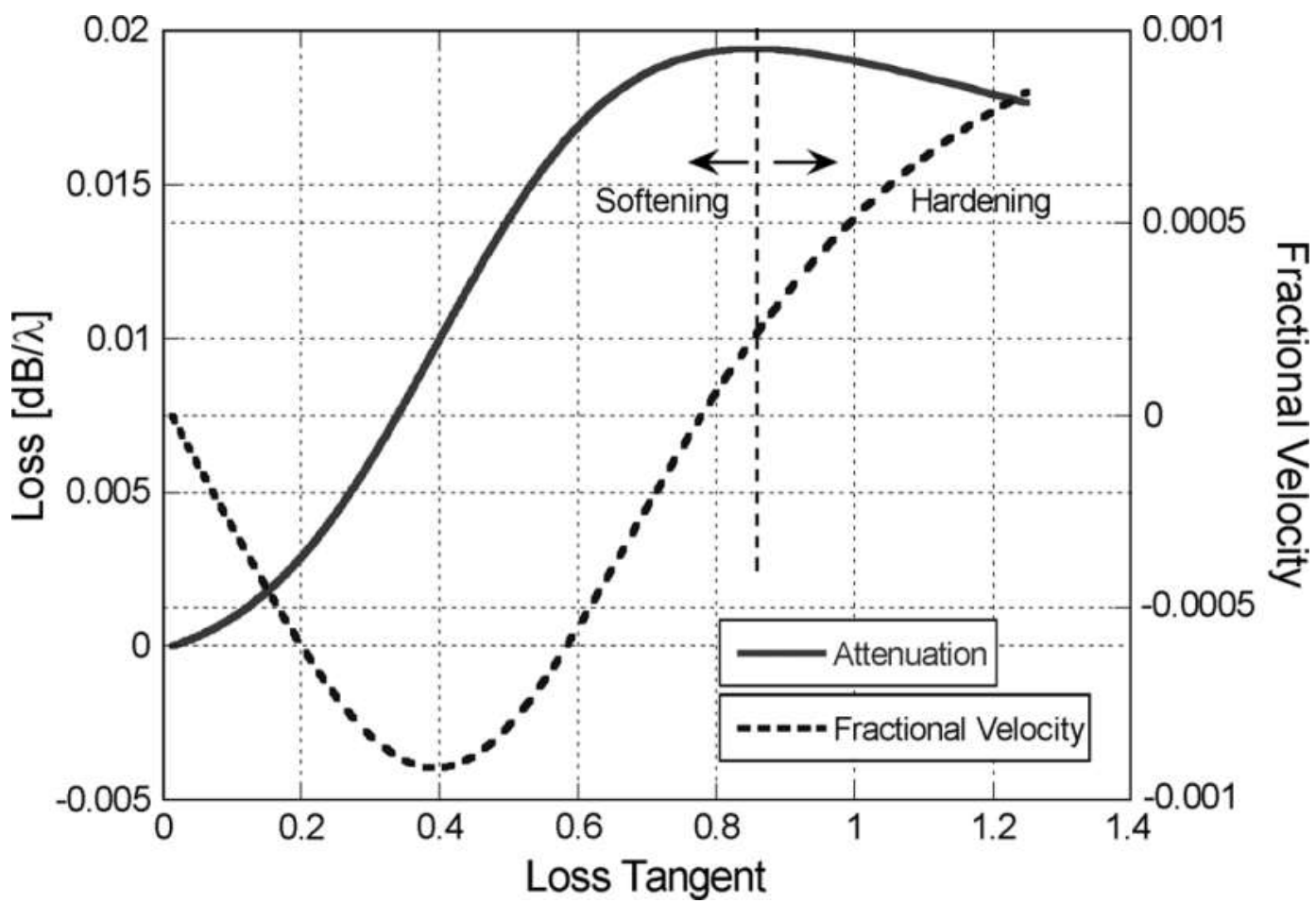

Fig. 8. Calculated sensor responses as a function of loss tangent $\left(G^{\prime \prime} / G^{\prime}\right)$ on the 3layer geometry assuming the characteristics of the liquid are unchanged before and

IEEE Sensors Journal, Vol 12, No. 5 (May 2012): pg. 893-903. DOI. This article is @ Institute of Electrical and Electronics Engineers (IEEE) and permission has been granted for this version to appear in e-Publications@Marquette. Institute of Electrical and Electronics Engineers (IEEE)] does not grant permission for this article to be further copied/distributed or hosted elsewhere without the express permission from Institute of Electrical and Electronics Engineers (IEEE). 
after perturbation. The polymer coating has a thickness of $0.5 \mu \mathrm{m}$ and the liquid has a density of $997.5542 \mathrm{~kg} / \mathrm{m3}$. G': $8 \times 108$ to $8 \times 107 \mathrm{~Pa}$; $\mathrm{G}^{\prime \prime}: 1 \times 107$ to $1 \times 108 \mathrm{~Pa}$.

In order to further understand and explain the sensor response, theoretical calculations were performed using approximate solution for the sensor response based on perturbation theory. ${ }^{6,31}$ In the calculations, the density and thickness of the film is kept constant at $1.15 \mathrm{~g} / \mathrm{cm}^{3}$ (BPA-HMTS) and $0.5 \mu \mathrm{m}$, respectively;

$$
v_{2} / \sqrt{P}=0.226 \times 10^{-5} \sqrt{\omega}[(\mathrm{m} / \mathrm{s}) / \sqrt{ }(\mathrm{W} / \mathrm{m})],{ }^{32}
$$

and the shear modulus is assumed to vary by a maximum of one order of magnitude upon exposure to $1 \mathrm{mg} / \mathrm{L}$ of analyte. Literature values are currently not available for the shear modulus at the operating frequency and thickness. Since BPA-HMTS is in the rubbery state at room temperature, simulation of the viscoelastic loading were performed using values in the range reported for rubbery polymers. ${ }^{9,16,32,33} \mathrm{Fig} .8$ is a simulation of the sensor response for the case where the film properties are changed upon analyte sorption and the characteristics of the liquid are unchanged before and after perturbation. It is seen that the attenuation (loss change) gradually increases and the fractional velocity decreases for the region where the loss tangent, $G^{\prime \prime} / G^{\prime}$, is less than or equal to 0.4 . This trend is in agreement with the measured response and confirms that the absorption of the analytes softens/plasticizes BPA-HMTS.

IEEE Sensors Journal, Vol 12, No. 5 (May 2012): pg. 893-903. DOI. This article is @ Institute of Electrical and Electronics Engineers (IEEE) and permission has been granted for this version to appear in e-Publications@Marquette. Institute of Electrical and Electronics Engineers (IEEE)] does not grant permission for this article to be further copied/distributed or hosted elsewhere without the express permission from Institute of Electrical and Electronics Engineers (IEEE). 


\section{Sensitivity, Partial Selectivity, and Limit of Detection}
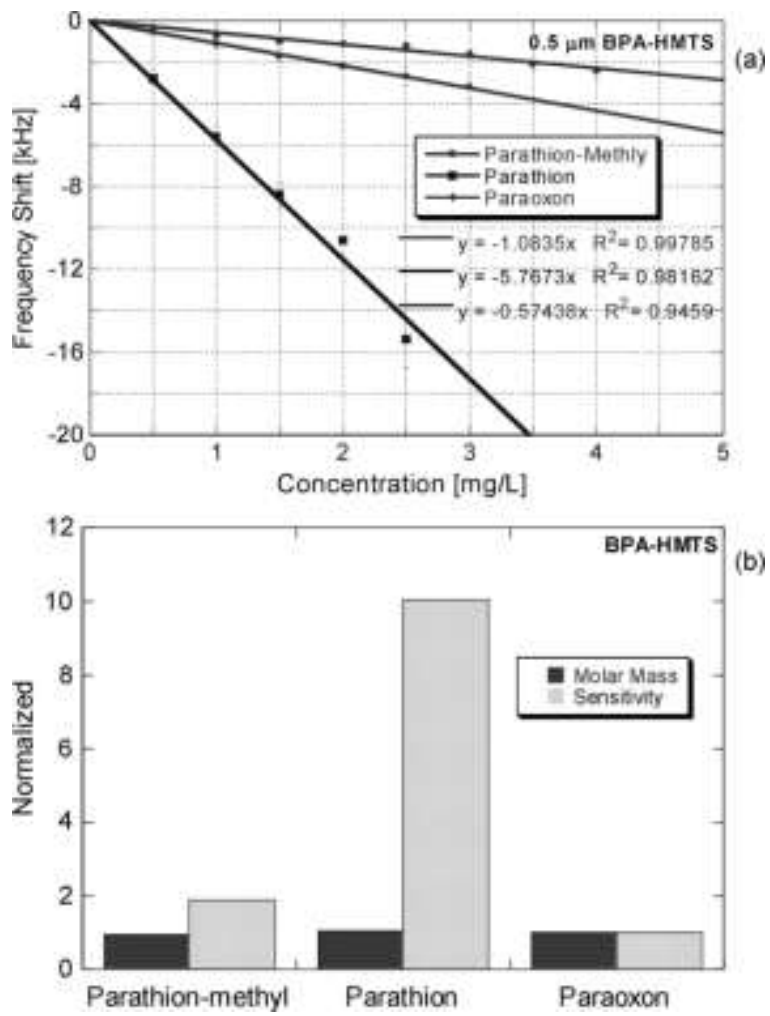

Fig. 9. (a) Sensitivity curve for the detection of parathion-methyl, parathion, and paraoxon in aqueous solution using a $0.5 \mu$ m-thick BPA-HMTS layer on $\mathrm{LiTaO}_{3} \mathrm{SH}-\mathrm{SAW}$ device. (b) Comparison of molar mass of OPs to the sensitivity of $0.5 \mu \mathrm{m}$-thick BPAcoated in their detection. All values have been normalized with respect to the corresponding value for paraoxon.

The coating, BPA-HMTS, synthesized in this work is partially selective and is sensitive to all the OPs, albeit to different levels. The empirical sensitivity $(S)$ of the BPA-HMTS towards the analytes was evaluated using the relation $\Delta f / \Delta C$, where $\Delta C$ is the change in concentration and its value is given by the slope of the sensitivity curve. The sensitivity of BPA-HMTS towards the analytes is shown in Fig. 9(a). It is noted that $\Delta f$ is determined when the response has reached steady-state upon exposure to a given concentration of analyte and the error bar represents the standard deviation for three measurements. The small error bars is an indication of the stability of the coating in aqueous solutions since for each analyte/coating pair the measurements were performed with the coating immersed in aqueous solution for at least 72 hours. Fig. 9(b) compares the molar mass of the analytes to the sensitivity of BPA-HMTS towards the analytes. All

IEEE Sensors Journal, Vol 12, No. 5 (May 2012): pg. 893-903. DOI. This article is @ Institute of Electrical and Electronics Engineers (IEEE) and permission has been granted for this version to appear in e-Publications@Marquette. Institute of Electrical and Electronics Engineers (IEEE)] does not grant permission for this article to be further copied/distributed or hosted elsewhere without the express permission from Institute of Electrical and Electronics Engineers (IEEE). 
values for a given analyte are normalized with respect to the corresponding value for paraoxon. Assuming that the same number of molecules was absorbed for each analyte, one would have expected the sensitivities to be identical if added mass was the dominant contribution to the measured frequency shift since the mass of the analytes are identical. However, this is not the case. To explain this difference, one has to consider the thermodynamic activities of the analytes.

Table II Linear Solvation Energy Relationship (LSER) Coefficients for BPAHMTS in the Gas Phase..$^{20}$ It Should Be Noted That Although These Coefficients Will Be Different in Water, It is Hypothesized That the Relative Relationships Presented Here for Gas Will Be the Same for Water. Thus, These Values Serve as a Guide for Understanding the Nature of the Analyte/Coating Interaction

\begin{tabular}{|c|c|c|c|c|c|c|}
\hline & $\boldsymbol{c}$ & $\boldsymbol{r}$ & $\boldsymbol{s}$ & $\boldsymbol{a}$ & $\boldsymbol{b}$ & $\boldsymbol{l}$ \\
\hline BPA & -2.00 & -0.92 & 2.24 & 2.79 & $\mathbf{2 . 4 1}$ & 0.975 \\
\hline
\end{tabular}

For relatively low concentrations, the frequency shift (added mass and viscoelastic change/degree of plasticization and swelling) is proportional to the amount of analyte absorbed by the coating. The amount of analyte absorbed depends on the polymer-liquid partition coefficient, which in turn depends on the analyte solubility parameters and the LSER coefficients for the polymer. For BPA-HMTS, the LSER coefficients (gas phase) are dictated by BPA (see Table II). It is noted that these coefficients will be different in the liquid phase, because of the water solubility factor. Thus, care must be exercised in using this table. However, for a given polymer, these coefficients are constant, with the key primary coefficients of interest here being hydrogen-bond acidity, indicated by the coefficient $b$. This coefficient describes the ability of the coating to interact with hydrogen-bond basic analytes. The solubility of parathion-methyl and parathion in aqueous solution are $38 \mathrm{mg} / \mathrm{L}$ and $12.9 \mathrm{mg} / \mathrm{L}$ at $20^{\circ} \mathrm{C}$, respectively, as reported in Table I. From these values, one may hypothesize that the analyte with the lowest solubility in aqueous solution, in this case parathion, partitions into the coating to a greater extent (i.e., larger polymerliquid partition coefficient) and hence more analyte being absorbed into the coating. This conclusion is in agreement with the trend

IEEE Sensors Journal, Vol 12, No. 5 (May 2012): pg. 893-903. DOI. This article is @ Institute of Electrical and Electronics Engineers (IEEE) and permission has been granted for this version to appear in e-Publications@Marquette. Institute of Electrical and Electronics Engineers (IEEE)] does not grant permission for this article to be further copied/distributed or hosted elsewhere without the express permission from Institute of Electrical and Electronics Engineers (IEEE). 
observed for the detection of aromatic compounds (toluene, xylene, and ethylbenzene) in liquid. ${ }^{29}$ In particular, it is seen that the response of the sensor to $3 \mathrm{ppm}$ of parathion-methyl and $1 \mathrm{ppm}$ of parathion did not yield the same frequency shift $(\sim 3 \mathrm{kHz})$, indicating that BPA-HMTS has some preferential selectivity for either analytes and that added mass is not the dominant contribution to the frequency shift. Therefore, the "true" selectivity of BPA-HMTS, is evaluated using the expression

$$
\text { Selectivity }=\frac{\Delta f}{\Delta C} \times \frac{C_{s a t}}{M_{w}}
$$

where $C_{\text {sat }}$ is the saturation concentration/solubility ( $\left.C_{s a t}\right)$ and $M_{W}$ is the molecular weight/molar mass of the analyte. Using (3), it is determined that BPA-HMTS is 1.63 times more selective to parathion than parathion-methyl. In performing this conversion, the solubility values for the analyte in water instead of water/methanol (data not available) and the molecular weight of the analytes are used. Nevertheless, this calculation does help to understand the selectivity of BPA-HMTS in relation to the number of analyte molecules absorbed and the thermodynamic activity of the analyte in aqueous solution.

From the chemical structures of the analytes, it is seen that the only difference between parathion-methyl and parathion is the alkyl substituents. ${ }^{4}$ The effect of the methyl group is to make the molecule more electrophilic/electronegative and hence more polar. Due to the polar nature of water, polar molecules are able to dissolve in water (i.e., "like dissolves like"), and hence the higher solubility of parathionmethyl. In other words, parathion-methyl prefers to be in aqueous solution as opposed to being in the coating. Similarly, the oxygen atom (a highly electronegative atom) in paraoxon makes it more soluble in water than parathion-methyl and parathion, respectively. It is noted that measurements of the analyte/coating partition coefficient using similar methods described in ${ }^{30,34}$ will provide further insight into the nature of the analyte/coating interaction.

The limit of detection (LOD) of a chemical sensor is defined as the minimum measurable concentration that corresponds to a frequency shift no smaller than three times the root-mean-square 
noise level. ${ }^{6,16}$ It is a function of both the sensitivity (S) and measurement noise $\left(\Delta f_{\text {noise }}\right)$ and is given by ${ }^{29}$

$$
L O D=\frac{3 \times \Delta f_{\text {noise }}}{S}
$$

The measurement noise is calculated by determining the rootmean-square of the signal in the reference solution. For the present measurements, the root-mean-square noise level for $\mathrm{LiTaO}_{3}$ devices coated with $0.5 \mu \mathrm{m}$-thick BPA-HMTS is $0.04 \mathrm{kHz}$. Using (4), a limit of detection of $60 \mu \mathrm{g} / \mathrm{L}(\mathrm{ppb}), 20 \mu \mathrm{g} / \mathrm{L}(\mathrm{ppb})$ and $100 \mu \mathrm{g} / \mathrm{L}(\mathrm{ppb})$ is estimated for parathion-methyl, parathion, and paraoxon respectively, when using a $0.5 \mu \mathrm{m}$-thick BPA-HMTS sensing layer. Note that concentrations as low as $500 \mu \mathrm{g} / \mathrm{L}$ (ppb) parathion have been actually measured in the present experiments. This concentration is significantly much lower than the typical concentrations found on agricultural produce ( $\geq 10 \mathrm{ppm}$ ). ${ }^{2}$ It is also noted that these limits could not be achieved with PECH in previous work. ${ }^{35}$

In order to optimize the sensor performance, the effects of the frequency of operation and film thickness on sensitivity were studied. First, the thickness of the BPA-HMTS layer on $\mathrm{LiTaO}_{3} \mathrm{SH}-\mathrm{SAW}$ device was decreased to $0.25 \mu \mathrm{m}$. In Fig. 10, it is seen that for concentrations greater than $4 \mathrm{mg} / \mathrm{L}$ of parathion, the slope of the curve begins to change; for concentrations $\leq 4 \mathrm{mg} / \mathrm{L}$ of parathion, one can fit the data with a linear function having an $R$-squared value of 0.99 . The value of $4 \mathrm{mg} / \mathrm{L}$ of parathion may be the concentration at which plasticization effect (hence viscoelastic loading) is significantly large and the region of linear behaviour with respect to analyte concentration is no longer valid. ${ }^{36}$ It is noted that for this thickness, $500 \mu \mathrm{g} / \mathrm{L}$ of parathion could not be detected with the present system. Next, the thickness of the BPA-HMTS layer was varied from $0.25 \mu \mathrm{m}$ to $1.23 \mu \mathrm{m}$. In Fig. 11, the frequency shifts upon exposure to $1 \mathrm{mg} / \mathrm{L}$ of parathion for different thicknesses of BPA-HMTS are normalized with respect to the frequency shift corresponding to $0.25 \mu \mathrm{m}$. It is noticed that the sensor sensitivity increases with increasing film thickness. This is due to the fact that the acoustic energy trapped to the surface increases with film thickness up to an optimum value. 7,8 The optimum thickness for BPA-HMTS was not determined in this work. Increasing acoustic energy at the surface makes the device more sensitive to surface perturbations. In addition,

IEEE Sensors Journal, Vol 12, No. 5 (May 2012): pg. 893-903. DOI. This article is @ Institute of Electrical and Electronics Engineers (IEEE) and permission has been granted for this version to appear in e-Publications@Marquette. Institute of Electrical and Electronics Engineers (IEEE)] does not grant permission for this article to be further copied/distributed or hosted elsewhere without the express permission from Institute of Electrical and Electronics Engineers (IEEE). 
as the layer thickness increases, the amount of free volume increases. Consequently, the amount of analyte absorbed increases, leading to increased softening or plasticization. It should be noted that, increasing film thickness also affects the sensor response time, another key design parameter, with thicker coatings exhibiting longer sensor response times.

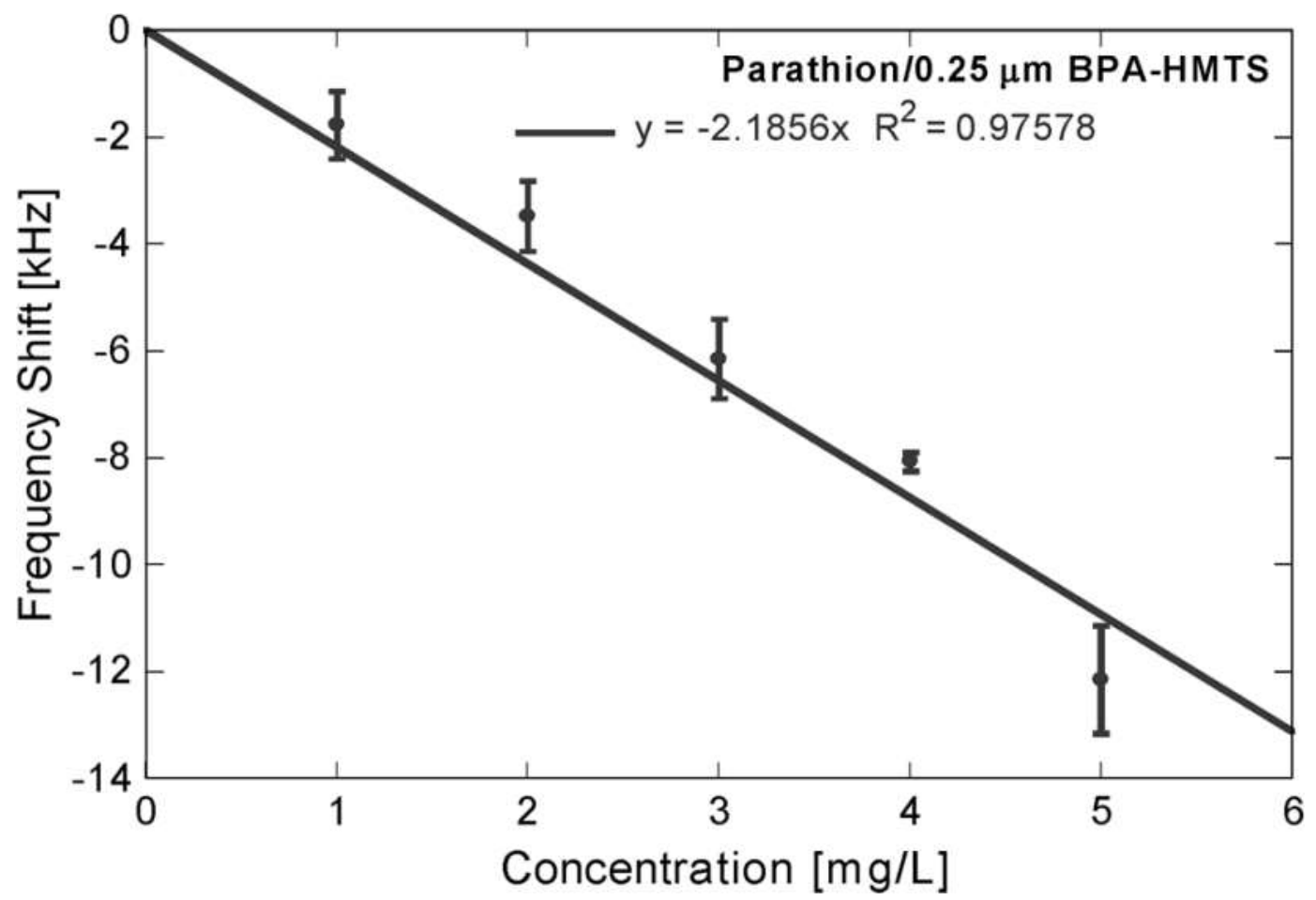

Fig. 10. Sensitivity curve for the detection of parathion absorbed by $0.25 \mu \mathrm{m}$-thick BPA-HMTS layer on $\mathrm{LiTaO}_{3} \mathrm{SH}-\mathrm{SAW}$ device.

IEEE Sensors Journal, Vol 12, No. 5 (May 2012): pg. 893-903. DOI. This article is @ Institute of Electrical and Electronics Engineers (IEEE) and permission has been granted for this version to appear in e-Publications@Marquette. Institute of Electrical and Electronics Engineers (IEEE)] does not grant permission for this article to be further copied/distributed or hosted elsewhere without the express permission from Institute of Electrical and Electronics Engineers (IEEE). 
NOT THE PUBLISHED VERSION; this is the author's final, peer-reviewed manuscript. The published version may be accessed by following the link in the citation at the bottom of the page.

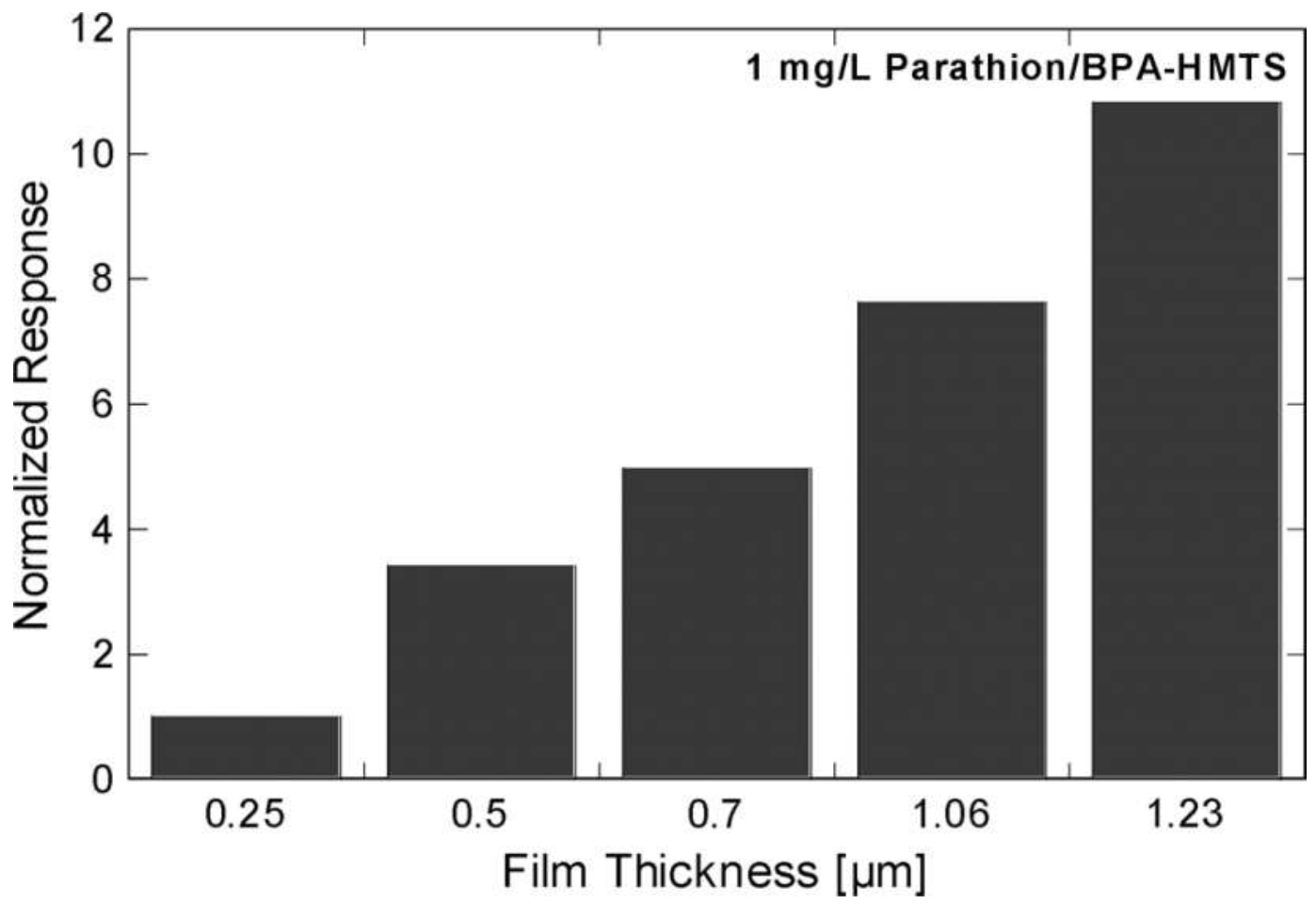

Fig. 11. Effect of BPA-HMTS layer thickness on sensitivity of $\mathrm{LiTaO}_{3} \mathrm{SH}-\mathrm{SAW}$ device.

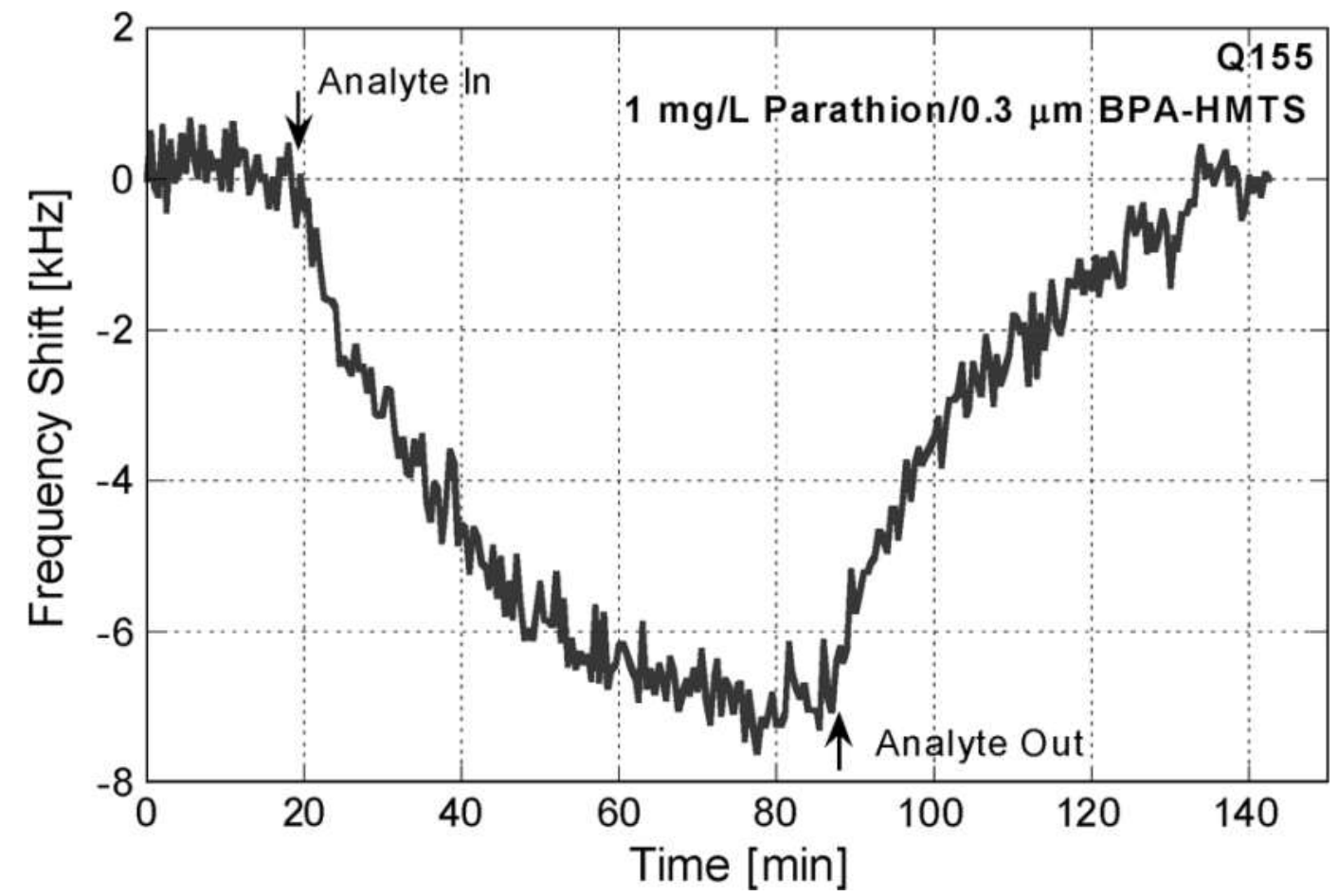

Fig. 12. Measured frequency shift in the detection of $1 \mathrm{mg} / \mathrm{L}$ of parathion using 0.3 $\mu$ m-thick BPA-HMTS layer on the propagation path of the Q155 device.

IEEE Sensors Journal, Vol 12, No. 5 (May 2012): pg. 893-903. DOI. This article is C Institute of Electrical and Electronics Engineers (IEEE) and permission has been granted for this version to appear in e-Publications@Marquette. Institute of Electrical and Electronics Engineers (IEEE)] does not grant permission for this article to be further copied/distributed or hosted elsewhere without the express permission from Institute of Electrical and Electronics Engineers (IEEE). 
Fig. 12 shows the frequency shift for a Q155 device coated with $0.3 \mu \mathrm{m}$-thick BPA-HMTS on the propagation path in the detection of 1 $\mathrm{mg} / \mathrm{L}$ of parathion. Even though the active sensing area and the film thickness are smaller when compared to the configuration used for LT103, the coated-Q155 device exhibits about the same level of sensitivity for $1 \mathrm{mg} / \mathrm{L}$ of parathion. The high sensitivity is due to the fact that the acoustic energy at the surface is proportional to the operating frequency of the device. The high noise level is due to the fact that the deposition of $0.3 \mu$ m-thick BPA-HMTS on the propagation path results in a lossy system. It is noted that there are some key design challenges that have to be resolved before the full potential of the Q155 device can be realized. They include minimizing the noise in the system, which is four times higher than that of the LT103 devices. As a result, the projected LOD will be relatively higher. Nevertheless, the results demonstrate the potential of improving the overall performance of the sensor system by using a high-frequency device.

\section{Comparison of Response Times for Different Coatings}

The term rapid response time was used in comparison with previous work done using different films and devices. ${ }^{3,4}$ For example, the sensor response time (t90), given by $2.3 *$ absorption time, is 100 min and 36 min for PECH and BPA-HMTS, respectively, for the same coating thickness exposed to $4 \mathrm{mg} / \mathrm{L}$ of parathion. This represented a $60 \%$ reduction in response time while maintaining the same sensitivity levels. ${ }^{4}$ As mentioned earlier, polymers with low $T_{g}$ are desirable for chemical sensing. Comparing the $T_{g}$ for $\mathrm{PECH}(-25.5 \circ \mathrm{C})$ to the $T_{g}$ for BPA-HMTS $\left(4.95^{\circ} \mathrm{C}\right)$, it was expected that $\mathrm{PECH}$ will be more rubbery at room temperature ${ }^{12}$ and thus will exhibit a faster absorption process. However, from the measurements, it was observed that the sensor response time compared to $\mathrm{PECH}$ is decreased by at least $60 \%$ and the sensitivity levels are on par. The faster response time of BPAHMTS is due to the inorganic part of the polymer i.e., HMTS. The porosity of HMTS increases the surface area-to-volume ratio. As a result, parathion is able to penetrate the surface of the coating rapidly and hence exhibits a faster absorption process. The sensitivity exhibited by BPA-HMTS is due to the organic part, i.e., BPA. BPA is a 
NOT THE PUBLISHED VERSION; this is the author's final, peer-reviewed manuscript. The published version may be accessed by following the link in the citation at the bottom of the page.

strong hydrogen-bond acidic coating and thus provides the medium for acid-base interactions with the strong hydrogen-bond basic analyte.

\section{Section V. Conclusions}

A partially selective, water-stable, hybrid coating (BPA-HMTS) has been synthesized and characterized for rapid absorption of organophosphates (OPs) on SH-SAW devices. With this coating, under the same experimental conditions i.e., thickness, a $60 \%$ reduction in the sensor response time has been achieved over $\mathrm{PECH}$ while maintaining the same sensitivity levels. Typically, in chemical sensor application, it is desired that the coating have a low glass transition temperature i.e., the coating should be rubbery at or near the operating temperature to promote rapid analyte absorption. However, the results of this study indicate that this is not a sufficient condition for rapid analyte absorption. Rather, the porosity of the coating appears to be the key coating feature for rapid analyte absorption. The faster absorption exhibited by BPA-HMTS is rather due to the porosity of the siloxane (HMTS) backbone while the BPA provides the chemical sensitivity of the coating. The coating exhibited different sensitivity levels towards the analytes. In fact, with respect to paraoxon, BPAHMTS exhibited about twice and 10 times higher sensitivity towards parathion-methyl and parathion, respectively, even though the analytes have identical molar masses. This suggests that the coating has different partition coefficients for the analytes. An analysis of the solubility of the analytes in water indicates that the least soluble analyte, in this case parathion, will prefer to be in the coating. As a result, the amount of parathion absorbed by the coated device is large in comparison to parathion-methyl and paraoxon. This results in greater plasticization leading to larger viscoelastic contribution to the sensor frequency shift. This argument is supported by the larger change in device loss observed upon exposure to parathion. With the present SH-SAW based chemical sensor, a limit of detection of $60 \mu \mathrm{g} / \mathrm{L}$ (ppb), $20 \mu \mathrm{g} / \mathrm{L}(\mathrm{ppb})$ and $100 \mu \mathrm{g} / \mathrm{L}(\mathrm{ppb})$ is estimated for parathionmethyl, parathion, and paraoxon, respectively, when using a $0.5 \mu \mathrm{m}$ thick BPA-HMTS sensing layer. Concentrations as low as $500 \mu \mathrm{g} / \mathrm{L}$ ( $p p b)$ parathion have been measured. This concentration is significantly much lower than the typical concentrations found on agricultural produce ( $\geq 10 \mathrm{ppm}$ ).

IEEE Sensors Journal, Vol 12, No. 5 (May 2012): pg. 893-903. DOI. This article is (C) Institute of Electrical and Electronics Engineers (IEEE) and permission has been granted for this version to appear in e-Publications@Marquette. Institute of Electrical and Electronics Engineers (IEEE)] does not grant permission for this article to be further copied/distributed or hosted elsewhere without the express permission from Institute of Electrical and Electronics Engineers (IEEE) 
NOT THE PUBLISHED VERSION; this is the author's final, peer-reviewed manuscript. The published version may be accessed by following the link in the citation at the bottom of the page.

\section{References}

${ }^{1}$ V. Pedrosa, J. Caetano, S. Machado, M. Bertotti, "Determination of parathion and carbaryl pesticides in water and food samples using a self assembled monolayer/acetylcholinesterase electrochemical Biosensor", Sensors, vol. 8, no. 8, pp. 46004610, 2008.

${ }^{2} \mathrm{~K}$. V. Ragnarsdottir, "Environmental fate and toxicology of organophosphate pesticides", J. Geological Soc., vol. 157, pp. 859-876, 2000.

${ }^{3}$ W. Pinkham, M. Wark, S. Winters, L. French, D. J. Frankel, J. F. Vetelino, "A lateral field excited acoustic wave pesticide sensor", Proc. IEEE Ultrason. Symp. 2005, vol. 4, pp. 2279-2283, 2005.

${ }^{4}$ A. K. Mensah-Brown, D. Mlambo, F. Josse, J. Hossenlopp, "Rapid detection of organophosphates in aqueous solution using a hybrid organic/inorganic coating on SH-SAW devices", Proc. 2010 IEEE Int. Frequency Control Symp., pp. 232-237, 2010.

${ }^{5} \mathrm{~T}$. Zhou, Theoretical Modeling of Acoustic Waves in Layered Structure Chemical Sensors and Biosensors, Marquette Univ., 1992.

${ }^{6} \mathrm{Z}$. H. Li, Y. Jones, J. Hossenlopp, R. Cernosek, F. Josse, "Analysis of liquid-phase chemical detection using guided shear horizontalsurface acoustic wave sensors", Analytical Chem., vol. 77, no. 14, pp. 4595-4603, July 2005.

${ }^{7}$ F. Josse, F. Bender, R. W. Cernosek, "Guided shear horizontal surface acoustic wave sensors for chemical and biochemical detection in liquids", Analytical Chem., vol. 73, no. 24, pp. 5937-5944, Dec. 2001.

${ }^{8}$ A. K. Mensah-Brown, M. J. Wenzel, F. J. Josse, E. E. Yaz, "Near realtime monitoring of organophosphate pesticides in the aqueousphase using SH-SAW sensors including estimation-based signal analysis", IEEE Sensors J., vol. 9, no. 12, pp. 1817-1824, Dec 2009.

${ }^{9}$ S. J. Martin, G. C. Frye, S. D. Senturia, "Dynamics and response of polymer-coated surface acoustic wave devices: Effect of viscoelastic properties and film resonance", Analytical Chem., vol. 66, no. 14, pp. 2201-2219, May 2002.

${ }^{10}$ D. S. Ballatine, R. M. White, S. J. Martin, A. J. Ricco, G. C. Frye, E. T. Zellers, H. Wohltjen, Acoustic Wave Sensors: Theory Design and

IEEE Sensors Journal, Vol 12, No. 5 (May 2012): pg. 893-903. DOI. This article is C Institute of Electrical and Electronics Engineers (IEEE) and permission has been granted for this version to appear in e-Publications@Marquette. Institute of Electrical and Electronics Engineers (IEEE)] does not grant permission for this article to be further copied/distributed or hosted elsewhere without the express permission from Institute of Electrical and Electronics Engineers (IEEE). 
Physico-Chemical Applications, CA, San Diego:Academic Press, 1997.

${ }^{11}$ A. Mensah-Brown, M. J. Wenzel, F. Josse, E. Yaz, O. Sadik, "Liquidphase detection of organophosphate pesticides using guided $\mathrm{SH}$ SAW sensor", IEEE Sensors, pp. 1420-1423, Oct. 2007.

12]. W. Grate, D. A. Nelson, "Sorptive polymeric materials and photopatterned films for gas phase chemical microsensors", Proc. IEEE, vol. 91, no. 6, pp. 881-889, Jun. 2003.

${ }^{13}$ A. Menon, R. N. Zhou, F. Josse, "Coated-quartz crystal resonator (QCR) sensors for on-line detection of organic contaminants in water", IEEE Trans. Ultrason. Ferroelect. Freq. Contr., vol. 45, no. 5, pp. 1416-1426, Sep. 1998.

14]. W. Grate, S. N. Kaganove, S. J. Patrash, R. Craig, M. Bliss, "Hybrid organic/inorganic copolymers with strongly hydrogen-bond acidic properties for acoustic wave and optical sensors", Chem. Mater., vol. 9, no. 5, pp. 1201-1207, May 1997.

${ }^{15}$ R. A. Mcgill, M. H. Abraham, J. W. Grate, "Choosing polymer-coatings for chemical sensors", Chemtech, vol. 24, no. 9, pp. 27-37, Sept. 1994.

${ }^{16}$ D. S. Ballantine, R. M. White, S. J. Martin, A. J. Ricco, G. C. Frye, E. T. Zellers, H. Wohltjen, Acoustic Wave Sensors: Theory Design and Physico-Chemical Applications, CA, San Diego:Academic Press, 1997.

17]. W. Grate, "Acoustic wave microsensor arrays for vapor sensing", Chemi. Rev., vol. 100, no. 7, pp. 2627-2647, Jul. 2000.

18]. W. Grate, D. A. Nelson, Polymers for Chemical Sensors Using Hydrosilylation Chemistry, 2001.

${ }^{19}$ J. W. Grate, M. H. Abraham, "Solubility interactions and the design of chemically selective sorbent coatings for chemical sensors and arrays", Sens. Actuators B: Chem., vol. 3, no. 2, pp. 85-111, Feb. 1991.

${ }^{20}$ M. H. Abraham, I. Hamerton, J. B. Rose, J. W. Grate, "Hydrogenbonding. Part 18. Gas-liquid-chromatographic measurements for the design and selection of some hydrogen-bond acidic phases suitable for use as coatings on piezoelectric sorption detectors", J. Chem. Soc.-Perkin Trans. 2, no. 9, pp. 1417-1423, Sep. 1991.

IEEE Sensors Journal, Vol 12, No. 5 (May 2012): pg. 893-903. DOI. This article is @ Institute of Electrical and Electronics Engineers (IEEE) and permission has been granted for this version to appear in e-Publications@Marquette. Institute of Electrical and Electronics Engineers (IEEE)] does not grant permission for this article to be further copied/distributed or hosted elsewhere without the express permission from Institute of Electrical and Electronics Engineers (IEEE). 
${ }^{21}$ R. P. Cowart, F. L. Bonner, E. A. Epps, "Rate of hydrolysis of seven organophosphate pesticides", Bull. Environ. Contamination Toxicol., vol. 6, no. 3, pp. 231-234, May 1971.

22]. W. Grate, S. N. Kaganove, S. J. Patrash, R. Craig, M. Bliss, "Hybrid organic/inorganic copolymers with strongly hydrogen-bond acidic properties for acoustic wave and optical sensors", Chem. Mater., vol. 9, no. 5, pp. 1201-1207, May 1997.

${ }^{23}$ C. Fest, K. J. Schmidt, The Chemistry of Organophosphorus Pesticides, New York:Springer-Verlag, 1973.

24]. H. Ruzicka, J. Thomson, B. B. Wheals, "The gas chromatographic determination of organophosphorus pesticides", J. Chromatogr., vol. 31, pp. 37-47, 1967.

${ }^{25} \mathrm{Y} . \mathrm{Ku}, \mathrm{J}$. L. Chang, "Effect of solution $\mathrm{pH}$ on the hydrolysis and photolysis of diazinon in aqueous solution", Water Air and Soil Pollution, vol. 108, pp. 445-456, 1998.

${ }^{26} \mathrm{~S}$. R. Fisher, Ground Water Quality in Kentucky: $p H$.

${ }^{27}$ L. Zhonghui, Y. Jones, J. Hossenlopp, R. Cernosek, F. Josse, "Chemical liquid-phase detection using guided SH-SAW: Theoretical simulation and experiments", Proc. 2003 IEEE Int. Frequency Control Symp. PDA Exhibit. Jointly With the 17th Eur. Frequency and Time Forum, pp. 918-926, 2003.

${ }^{28}$ E. Gizeli, F. Bender, A. Rasmusson, K. Saha, F. Josse, R. Cernosek, "Sensitivity of the acoustic waveguide biosensor to protein binding as a function of the waveguide properties", Biosens. Bioelectron., vol. 18, no. 11, pp. 1399-1406, Oct. 2003.

${ }^{29} \mathrm{Z}$. H. Li, Guided Shear-Horizontal Surface Acoustic Wave (SH-SAW) Chemical Sensors for Detection of Organic Contaminants in Aqueous Environments, Marquette University, 2005.

${ }^{30} \mathrm{~J}$. W. Grate, M. Klusty, R. A. McGill, M. H. Abraham, G. Whiting, J. Andonianhaftvan, "The predominant role of swelling-induced modulus changes of the sorbent phase in determining the responses of polymer-coated surface acoustic-wave vapor sensors", Analytical Chem., vol. 64, no. 6, pp. 610-624, Mar. 1992.

${ }^{31}$ B. A. Auld, Acoustic Fields and Waves in Solids, FL, Malabar:Krieger, 1990.

32]. Kondoh, S. Shiokawa, M. Rapp, S. Stier, "Simulation of viscoelastic effects of polymer coatings on surface acoustic wave gas sensor under consideration of film thickness", Jpn. J. f Appl. Phys. P .1-

IEEE Sensors Journal, Vol 12, No. 5 (May 2012): pg. 893-903. DOI. This article is C Institute of Electrical and Electronics Engineers (IEEE) and permission has been granted for this version to appear in e-Publications@Marquette. Institute of Electrical and Electronics Engineers (IEEE)] does not grant permission for this article to be further copied/distributed or hosted elsewhere without the express permission from Institute of Electrical and Electronics Engineers (IEEE). 
NOT THE PUBLISHED VERSION; this is the author's final, peer-reviewed manuscript. The published version may be accessed by following the link in the citation at the bottom of the page.

Reg. Papers Short Notes \& Review Papers, vol. 37, no. 5B, pp. 2842-2848, May 1998.

${ }^{33} \mathrm{~S}$. J. Martin, G. C. Frye, "Polymer film characterization using quartz resonators", Proc. 1991 IEEE Ultrasonics Symp., pp. 393-398, 1991.

${ }^{34}$ A. Urbanczyk, J. Staniewski, J. Szymanowski, "Abraham model in gas chromatography of phenol pollutants", Analytica Chimica Acta, vol. 466, no. 1, pp. 151-159, 2002.

${ }^{35} \mathrm{~A}$. K. Mensah-Brown, Detection of Organophosphates in the LiquidPhase Using Guided SH-SAW Sensors, Marquette University, 2007.

${ }^{36}$ A. Hierlemann, A. J. Ricco, K. Bodenhofer, W. Gopel, "Effective use of molecular recognition in gas sensing: Results from acoustic wave and in situ FT-IR measurements", Analytical Chem., vol. 71, no. 15, pp. 3022-3035, June 1999.

IEEE Sensors Journal, Vol 12, No. 5 (May 2012): pg. 893-903. DOI. This article is @ Institute of Electrical and Electronics Engineers (IEEE) and permission has been granted for this version to appear in e-Publications@Marquette. Institute of Electrical and Electronics Engineers (IEEE)] does not grant permission for this article to be further copied/distributed or hosted elsewhere without the express permission from Institute of Electrical and Electronics Engineers (IEEE). 